\title{
UM ESTUDO SOBRE O POSSÍVEL PROCESSO DE DESINDUSTRIALIZAÇÃO EM PAÍSES MEMBROS DO MERCOSUL: UMA VERIFICAÇÃO SOB A ÓTICA DAS POLÍTICAS ECONÔMICAS DO PERÍODO 1990-2012
}

\author{
Marcos Taroco Resende \\ Talles Girardi de Mendonça ${ }^{2}$ \\ Anderson Vitor Moreira ${ }^{3}$ \\ Taytiellen Fernandes Alves ${ }^{4}$ \\ Victor Ali Nogueira Abdul Rahman Ayoub
}

\begin{abstract}
RESUMO
O trabalho teve como objetivo verificar a ocorrência de um possível fenômeno da desindustrialização nos países membros do MERCOSUL e sua relação com as políticas econômicas implementadas entre 1990 e 2012. Um possível processo de desindustrialização em nível regional pode debilitar o projeto de integração regional do Mercosul pela importância que a indústria possui no desenvolvimento em longo prazo. Como procedimentos metodológicos, a pesquisa bibliográfica visou primeiramente apreender o conceito de desindustrialização e a discussão das suas possíveis causas. Além disso, verificou-se os indicadores que nortearam a etapa da pesquisa quantitativa, a saber, participação do produto industrial no PIB, participação da indústria de transformação no produto industrial, participação do emprego industrial no emprego total, composição da pauta de exportações. Ademais, buscou-se na bibliografia as políticas econômicas específicas implementadas em cada país. Os resultados das pesquisas sugerem diferentes diagnósticos para cada país, em diferentes subperíodos de tempo. Não foi possível diagnosticar que o Brasil passou por um processo de desindustrialização. Para Argentina e Uruguai as evidências analisadas sugerem o processo para a década de 1990 com a abertura comercial e financeira das economias e das políticas econômicas de estabilização, parcialmente revertido na década de 2000 , quando algumas mudanças foram introduzidas na gestão macroeconômica. Essa reversão da desindustrialização ocorreu com maior intensidade no Uruguai. No Paraguai observou-se uma estagnação dos indicadores. O baixo nível de desenvolvimento industrial do país e a escassa literatura sobre o tema não permitiram realizar uma conclusão.
\end{abstract}

Palavras-chave: Desindustrialização. MERCOSUL. Pauta exportadora.

\footnotetext{
${ }^{1}$ Graduado em Ciências Econômicas na Universidade Federal de São Joõ Del-Rei. Atualmente é Bolsista CAPES do Mestrado em Economia pela Universidade Federal de Alfenas (UNIFAL-MG). Universidade Federal de Alfenas (UNIFAL-MG - Campus Varginha). Minas Gerais. Brasil. E-mail: marcostaroco07@hotmail.com

${ }^{2}$ Doutor em Economia Aplicada pela Universidade Federal de Viçosa. Professor Adjunto III no Departamento de Ciências Econômicas da Universidade Federal de São João Del-Rei. Minas Gerais. Brasil. E-mail: tallesgm@ufsj.edu.br

${ }^{3}$ Graduado em Ciências Econômicas pela Universidade Federal de São João Del-Rei. Minas Gerais. Brasil. Email: andersonvitor@,rocketmail.com

${ }^{4}$ Graduada em Ciências Econômicas pela Universidade Federal de São João Del-Rei. Atualmente é mestranda em Economia Aplicada na Universidade Federal de Viçosa. Minas Gerais. Brasil. E-mail: taytiellen@hotmail.com

${ }^{5}$ Graduado em Ciências Econômicas pela Universidade Federal de São João Del-Rei. Minas Gerais. Brasil. Email: victorrahman@hotmail.com
}

DRd - Desenvolvimento Regional em debate (ISSNe 2237-9029)

v. 8 , n. 1, p. 90-117, jan./jun. 2018. 


\title{
A STUDY ABOUT THE POSSIBLE DESINDUSTRIALIZATION PROCESS IN MERCOSUR: A VERIFICATION THROUGH THE OPTICS OF ECONOMIC POLICIES IN THE PERIOD OF 1990-2012.
}

\begin{abstract}
This work aimed to verify the occurrence of a possible phenomenon of deindustrialization within MERCOSUR countries and its relations to economic policy implemented from 1990 to 2012. A possible deindustrialization process at the regional level can weaken the project of regional integration under MERCOSUR because of the importance that industry have to development in the long run. As methodological instruments the bibliographical research objected to understand the deindustrialization concept and the discussion about its causes. Moreover, it was verified indicators that guided the quantitative research. These are the participation of industrial product in Gross Domestic Product, participation of manufacturing in industrial product, employment in industry in relation to employment of the total economy and export list composition. Furthermore, it was searched in bibliography the specific economic policy implemented in each country. The results of the research suggest different diagnoses for each country, in different sub periods of time. It was not possible to diagnose that Brazil underwent a deindustrialization process. For Argentina and Uruguay, the evidence analyzed suggests the process for the 1990s with commercial and financial opening and economic policy for stabilization, partially reversed in the 2000 s when were introduced some changes in the economic policies. These reversal of desindustrialization occurred with more intensity in Uruguay. In Paraguay there was a stagnation of the indicators. The low level of industrial development of the country and the scarce literature on the Subject does not allow a conclusion to be drawn.
\end{abstract}

Keywords: Desindustrialization. MERCOSUR. Export agenda.

\section{INTRODUÇÃO}

O Mercado Comum do Sul (MERCOSUL) é uma experiência de integração regional que foi gestada por Brasil e Argentina na segunda metade da década de $1980^{6}$. Seus objetivos foram fundados a partir das crises das respectivas ditaduras militares e visavam fortalecer a democracia e a integração econômica entre os países. Com o Tratado de Assunção em 1991, Paraguai e Uruguai foram incorporados ao processo de integração regional (ALMEIDA, 2011; MORINI; SIMÕES 2002).

No artigo 1 do capítulo 1 do documento oficial do Tratado de Assunção estão constados os objetivos do Mercosul, que são:

a) A livre circulação de bens, serviços e fatores produtivos entre os países, através, entre outros, da eliminação dos direitos alfandegários e restrições não tarifárias à circulação de mercadorias e de qualquer outra medida de efeito equivalente;

\footnotetext{
${ }^{6}$ Conforme Almeida (2011) os primeiros passos do Mercosul foram esboçados primeiramente na cooperação e na complementação econômica, no Programa de Integração e Cooperação (1986), e no ano de 1988 o projeto de um mercado comum bilateral entre Brasil e Argentina, pelo Tratado de Integração (ALMEIDA, 2011).
}

DRd - Desenvolvimento Regional em debate (ISSNe 2237-9029) 
b) O estabelecimento de uma tarifa externa comum e a adoção de uma política comercial comum em relação a terceiros Estados ou agrupamentos de Estados e a coordenação de posições em foros econômico-comerciais regionais e internacionais;

c) A coordenação de políticas macroeconômicas e setoriais entre os Estados Partes de comércio exterior, agrícola, industrial, fiscal, monetária, cambial e de capitais, de serviços, alfandegárias, de transporte e comunicações e outras que se acordem, a fim de assegurar condições adequadas de concorrência entre os Estados Partes, e

d) O compromisso dos Estados Partes de harmonizar suas legislações, nas áreas pertinentes, para lograr o fortalecimento do processo de integração" (BRASIL, 1991).

Com o aprimoramento institucional desde o Tratado de Assunção, que definiu os termos de adesão, novos países ingressaram como Estados Partes (membros efetivos) como a Venezuela em 2006 e a Bolívia que está em processo de incorporação desde 2015. Não obstante há uma série de Estados Associados, como Chile, Colômbia, Equador, Guiana Francesa, Peru e Suriname (MERCOSUR, 2018).

A escolha dos Estados membros da formação inicial pode ser justificada pela inviabilidade da análise da desindustrialização no período escolhido, visto que seria possível analisar a Venezuela apenas a partir de 2004 e a Bolívia ainda está em processo de adesão.

No que se refere à integração econômica regional, Cavusgil et al. (2010) aponta que a formação de blocos econômicos se dá com mais êxito, dentre outras causas, sobretudo quando há similaridade econômica, cultural e social entre os países que comporão o bloco, bem como proximidade geográfica. O Mercado Comum do Sul (MERCOSUL), ainda segundo o autor é classificado como União Aduaneira, que é um tipo de bloco econômico no qual figuram eliminação de barreiras ao comércio pelos países membros bem como harmonização das políticas comerciais/tarifárias em relação a não membros. Contudo, alguns autores categorizam o Mercosul como uma União Aduaneira imperfeita, isto é, um estágio intermediário entre a Área de Livre Comércio e a União Aduaneira ${ }^{7}$.

A importância do estudo reside na análise das transformações pelas quais a estrutura econômica dos países que compõem o Mercosul têm passado nas últimas décadas. Ao conceber o estudo da desindustrialização não só em um país, mas para um grupo de países, pode-se lançar um olhar geral sobre a tendência contemporânea da importância do setor industrial no Mercosul e a sua importância para a inserção do bloco econômico na economia global.

O presente estudo tem como foco principal a indústria, assentando-se na perspectiva de que esta possui uma série de benefícios para o sistema econômico de um país, tais como os efeitos de encadeamentos para frente e para trás mais fortes que em outros setores, a presença de economias de escala, a notável capacidade de progresso tecnológico e difusão dos frutos do progresso técnico a partir desta para o restante da economia e a importância do setor industrial para alívio de restrições do balanço de pagamentos e do crescimento econômico, tendo em

\footnotetext{
${ }^{7}$ Conforme Morini e Simões (2002, p.140) “[...] o Mercosul é considerado um processo de integração econômica, denominado Mercado Comum, cuja fase atual é a União Aduaneira Imperfeita, por ainda existir lista de exceções às isenções tarifárias de importação e por haver indefinições temporais na aplicação da Tarifa Externa Comum (TEC)"
} 
vista que a elasticidade renda de importações no setor de manufaturas é maior que a de commodities e produtos primários (OREIRO; FEIJÓ, 2010).

Em resposta a crise de 1929 os países da América Latina em geral lançaram-se numa nova estratégia de desenvolvimento econômico, que tinha como espinha dorsal a industrialização. Essa estratégia foi fortalecida após a Segunda Guerra Mundial com as contribuições teóricas da CEPAL que criticavam o modelo agroexportador latino-americano ${ }^{8}$ (FONSECA, 2003). O Processo de Substituição de importações (PSI), de maneira geral, tornou-se uma estratégia de desenvolvimento predominante até os anos de 1980, quando a região percorreu a "década perdida" e posteriormente experimentou uma década de reformas liberalizantes que foram de encontro com a experiência industrializante e estatizante vivida pela América Latina desde os anos de 1930 (BATISTA, 1994; CANO, 2012).

Desta forma, tem-se como justificativas do trabalho a possível debilidade que o processo de desindustrialização causa na integração econômica proposta pelo Mercosul, a importância que a indústria tem no desenvolvimento econômico de longo prazo dos países, a possível regressão da importância da indústria ocasionada por um possível processo de "desindustrialização".

O trabalho visa contribuir para a literatura ao analisar o processo de industrialização num bloco econômico, visto que há escassa produção científica a respeito do processo no MERCOSUL.

O objetivo geral do trabalho é verificar a possível ocorrência da desindustrialização nos países do Mercosul. Os objetivos específicos são 1) analisar a relação entre desempenho industrial e as políticas econômicas adotadas nos países membros da formação original do Mercosul e 2) avaliar a inserção internacional do Mercosul à economia global pela pauta exportadora.

Deste modo, o trabalho visa responder se os países da formação inicial do Mercosul Argentina, Brasil, Paraguai e Uruguai - estão ou não passando por um processo de desindustrialização e quais seriam as possíveis causas associadas a tal processo (caso se chegue a uma eventual conclusão afirmativa no que tange ao Mercosul como um todo ou a um país).

$\mathrm{Na}$ metodologia a pesquisa bibliográfica visou primeiramente apreender o conceito de desindustrialização e a discussão das suas possíveis causas, pela qual verificou-se os indicadores que nortearam a etapa da pesquisa quantitativa, a saber, participação do produto

\footnotetext{
${ }^{8}$ No quadro conceitual da Cepal, havia de um lado os países centrais (desenvolvidos) e que possuíam um considerável progresso tecnológico e, de outro lado, os países periféricos (subdesenvolvidos) e com uma pauta exportadora de poucos produtos primários (1 ou 2 produtos), com baixa produtividade, grandes propriedades improdutivas etc., o que acarretava invariáveis problemas no balanço de pagamentos. Essa assimetria econômica condenava os países periféricos ao subdesenvolvimento, expressado por um lugar subordinado na divisão internacional do trabalho, em função da pauta de importação dos países centrais (importavam alimentos e produtos básicos) e países periféricos (importam bens de consumo industriais, intermediários e de capital). $\mathrm{O}$ comércio internacional entre essas duas categorias básicas de países acarreta na deterioração dos termos de intercâmbio (primeiro List, no século XIX e defensor latino-americano Prebisch) - que consiste na constatação de que os países especializados em exportação de produtos primários tendem a perder com o comércio internacional, pois 1) os preços relativos de seus produtos de exportação têm uma tendência de queda maior nas crises do que os dos industriais e 2) há uma tendência de longo prazo de queda de preços. (FONSECA, op.cit).
}

DRd - Desenvolvimento Regional em debate (ISSNe 2237-9029) 
industrial no PIB, participação da indústria de transformação no produto industrial, participação do emprego industrial no emprego total, composição da pauta de exportações. Ademais, buscou-se na bibliografia as políticas econômicas específicas implementadas em cada país, como luz interpretativa.

A hipótese trabalhada no artigo é que em geral os países estão passando por um processo de desindustrialização, porém, dada a diferença das estruturas produtivas de cada país este processo está se desenrolando em diferentes graus, porém com causas associadas à "nova doença holandesa", isto é, às políticas de estabilização e reformas liberalizantes da política econômica dos anos 90 . E a partir da década de 2000 o processo tendeu a consolidarse.

O trabalho é composto por quatro seções, além desta introdução. A seção dois trata do referencial teórico utilizado pelo artigo na definição do conceito de desindustrialização. Na seção três serão apresentadas a metodologia, consistindo em uma revisão da literatura e uma pesquisa quantitativa. Em seguida, na seção cinco, os resultados serão apresentados e analisados conforme os objetivos do trabalho. Não obstante, na seção cinco toma-se nota de algumas considerações, tendo em vista os resultados encontrados.

\section{REFERENCIAL TEÓRICO}

O tema da desindustrialização tem sido alvo de muitos estudos e debates desde a década de 1990, de forma que há uma preocupação em analisar a possibilidade de um processo de desindustrialização na economia brasileira, e o quão danoso ou benéfico isso pode ser.

Quando se fala em desindustrialização, refere-se à definição clássica dada por Rowtorn e Ramaswany (1999 apud OREIRO; FEIJÓ, 2010, p.220) como sendo "uma redução persistente da participação do emprego industrial no emprego total de um país ou região" e na ampliação do conceito realizada por Tregenna (2009 apud ibidem) de que não só o emprego industrial se reduz como proporção do emprego total, mas também a redução do produto industrial como proporção do Produto Interno Bruto $(\mathrm{PIB})^{10}$.

Cano (2012) considera importante para o entendimento do processo de desindustrialização saber o conceito de desenvolvimento e subdesenvolvimento econômico. Desse modo, o autor coloca que o processo de desenvolvimento ocorre quando há crescimento econômico acompanhado de aumento da produtividade média. Assim, quando o

\footnotetext{
9 A denominação de "doença holandesa" advém da experiência da Holanda nos anos 70, onde houve uma apreciação cambial pela entrada massiva de capitais externos em função da descoberta de gás natural, levandose à reprimarização da pauta de exportações do país (NASSIF, 2008; OREIRO; FEIJÓ, 2010). Já a "nova doença holandesa" refere-se à associação a condução de políticas macroeconômicas.

${ }^{10}$ Os autores enfatizam que pelo conceito ampliado assinala-se que o processo de desindustrialização pode se desenvolver mesmo diante da situação em que há a ocorrência de crescimento industrial absoluto, pois, o que caracteriza o fenômeno é a perda de importância relativa na geração de empregos e no valor adicionado da indústria na economia (OREIRO; FEIJÓ, op.cit, p.221).
}

DRd - Desenvolvimento Regional em debate (ISSNe 2237-9029)

v. 8 , n. 1, p. $90-117$, jan./jun. 2018. 
país passa pelo processo de desenvolvimento obtém-se maior renda per capta e forte redução da participação agrícola no PIB e também no que se refere ao emprego.

Neste sentido, Cano (2012) destaca que no processo de industrialização foram poucos os países - Brasil, Argentina e México - que conseguiram expandir a industrialização para além da produção de bens não duráveis de consumo e do beneficiamento industrial de produtos primários. Dentre os que conseguiram inserir um parque industrial mais avançado, somente o Brasil conseguiu prosperar de forma parcial no setor de bens de capital.

Tanto Oreiro e Feijó (2010) quanto Cano (op.cit) apontam que a desindustrialização pode ser ocasionada pelo progresso do processo de desenvolvimento econômico, pois a partir de um certo nível de renda per capta haveria a tendência natural de redução relativa da indústria no PIB. Tal fato ocorreria devido á elasticidade renda da demanda de serviços que caminhariam no sentido de expansão, juntamente com o desenvolvimento econômico, fazendo com que desse modo, a elasticidade renda de manufaturados fosse menor. Assim, o desenvolvimento econômico seria capaz de aumentar a presença dos serviços no PIB, reduzindo a participação da indústria. No entanto esses autores não acreditam que a desindustrialização no Brasil e em outros países subdesenvolvidos seja resultado natural do desenvolvimento econômico.

Oreiro e Feijó (2010) denominam de "desindustrialização precoce" a situação em que o processo de desindustrialização não é causado pelo seu curso natural de desenvolvimento a partir de um determinado nível per capita e mais pela "doença holandesa" a um nível inferior ao registrado nos países desenvolvidos.

Sem embargo, Nassif (2008) enfatiza que argumentos de que a economia brasileira esteve passando por um processo de desindustrialização, associam o dito processo à ideia de "nova doença holandesa", definida por Palma, 2005 (apud NASSIF, op.cit) como resultante de um conjunto de políticas econômicas liberalizantes e mudanças institucionais após a perturbada década de 1980, que trouxeram efeitos negativos sobre a indústria a partir da apreciação do real e da reprimarização da pauta de exportações.

Cano (2012) afirma que a desindustrialização no Brasil ocorre devido a vários fatores. Entre eles está o cambio sobrevalorizado, que desde o plano Real vem sendo usado como meio de controle inflacionário, aliado a uma política de juros altos e âncora fiscal. Outro ponto ressaltado pelo autor é a massiva redução de tarifas iniciada no governo Sarney, intensificada durante o mandato de Collor e mantida no governo de Fernando Henrique Cardoso.

Oreiro e Feijó (2010), também são favoráveis à tese de que há um processo de desindustrialização em marcha no Brasil. Os autores destacam as conclusões de Marquetti (2002 apud OREIRO; FEIJÓ, op.cit) acerca do tema, que apontam na direção de uma suposta perda de participação do emprego e também do valor adicionado, nas décadas de 80 e 90.

Em contrapartida a estes argumentos favoráveis à existência do processo de desindustrialização, estão as conclusões obtidas por Nassif (2008). Segundo o autor, quando uma economia atinge elevado nível de produção industrial, a tendência é de que a participação desta caia, e o setor de serviços aumente sua participação. Quanto à participação de manufaturados e produtos primários segundo intensidade tecnológica na pauta de exportações brasileiras, o autor elucida: 
As vendas externas de manufaturados representavam $85 \%$ do total das exportações brasileiras em 2005 (contra 88\% em 1989). Note ainda que, não obstante os impactos imediatos da liberalização comercial e da sobrevalorização do Real durante o período 1994-1998, a participação de produtos primários e de manufaturados na pauta exportadora brasileira manteve-se praticamente inalterada entre 1989 e 1999 (em torno de $11 \%$ e $88 \%$, respectivamente) (NASSIF, 2008, p. 90).

Outros trabalhos também se opõem à existência do processo de desindustrialização. Por exemplo, Bonelli e Pessôa (2010) enfatizam que a abertura comercial proporcionou a incorporação de novas máquinas e técnicas, o que gerou ganhos de produtividade. Os dois últimos autores afirmam ainda que a perda de participação relativa do produto industrial no PIB no Brasil acompanhou tendência natural mundial. Isso foi devido aos aumentos na produtividade e outros fatores.

Além disso, os autores indicam que há uma diferença de método que pode influir no resultado, pois comparando-se uma analise que utiliza preços correntes com uma que utiliza preços constantes, nota-se que a primeira apresenta queda mais acentuada da participação da indústria na economia, ao passo que a segunda apresenta um grau de queda menor.

No que diz respeito ao investimento, no comparativo entre 1996 e 2007, Bonelli e Pessôa (2010) afirmam não haver desindustrialização, pois "[...] a comparação das participações entre 1996 e 2007 mostra que houve forte aumento entre esses dois anos: de $14,4 \%$ para 20,1\%. Não há, portanto, evidência de desindustrialização quanto à evolução do investimento fixo". (BONELLI; PESSÔA, 2010, p. 31).

Schwartsman (2009) insere-se na discussão opondo-se à existência de desindustrialização no Brasil. Para o autor, analisando-se os dados, não se pode afirmar que a indústria brasileira vem perdendo participação. Em sua visão não se pode acreditar que uma taxa de câmbio depreciada seria a solução dos problemas referentes ao comércio internacional. $\mathrm{O}$ autor defende a ideia de que a diversificação e modernização do parque industrial brasileiro só foram possíveis devido à abertura comercial.

\section{Conforme o autor,}

De fato, o crescimento, não só da produção industrial, mas do PIB, acelerou-se consideravelmente até setembro de 2008 . No que se refere à primeira, a taxa média de expansão em quatro anos atingiu algo como 4,5\% ao ano, quase três vezes superior à registrada em períodos anteriores. Além disto, como já destacado aqui, o crescimento foi liderado pelos setores de maior intensidade exportadora, fenômeno difícil de conciliar com a afirmação acerca da influência negativa do câmbio sobre a atividade industrial (SCHWARTSMAN, 2009).

Quanto ao argumento de que há uma reprimarização da pauta exportadora brasileira, Schwartsman (2009) afirma que não houve diminuição da exportação de manufaturados, e sim um alto incremento na quantidade e nos preços dos produtos primários:

[...] se é verdade que houve queda da participação de manufaturados na pauta exportadora, tal queda não resultou da redução (ou desempenho medíocre) das exportações de manufaturados, que cresceram além do comércio internacional nos últimos anos (até a crise), mas sim da expansão excepcional dos produtos primários, impulsionados pelo aumento extraordinário dos preços internacionais de commodities (SCHWARTSMAN, 2009).

DRd - Desenvolvimento Regional em debate (ISSNe 2237-9029) 
É a partir das controvérsias no âmbito da economia brasileira que este trabalho se baseará na discussão e avaliação da possível ocorrência deste processo e suas causas ao nível dos países membros originais do Mercosul.

\section{METODOLOGIA}

Na realização deste trabalho, foram utilizadas a pesquisa bibliográfica e documental e a pesquisa quantitativa como métodos.

Conforme Gil (2002, p.44) “A pesquisa bibliográfica é desenvolvida com base em material já elaborado, constituído principalmente de livros e artigos científicos".

$\mathrm{Na}$ realização da pesquisa bibliográfica remeteu-se principalmente às publicações periódicas, definidas como "[...] aquelas editadas em fascículos, em intervalos regulares ou irregulares, com a colaboração de diversos autores, tratando de assuntos diversos, embora relacionado a um objetivo mais ou menos definido" (ibidem, p.45). Já na pesquisa documental buscou-se principalmente dados secundários.

Segundo Gil (2002) a pesquisa documental diferencia-se fundamentalmente da pesquisa bibliográfica por ter como base documentos que não receberam um tratamento analítico. Os exemplos mais comuns de dados secundários citados pelo autor são relatórios de pesquisa, relatórios de empresa e tabelas estatísticas. Os dados estatísticos foram insumos na pesquisa quantitativa.

De acordo com o objetivo geral, a pesquisa pode ser classificada como explicativa, pois ditas "[...] pesquisas têm como preocupação central identificar os fatores que determinam ou que contribuem para a ocorrência dos fenômenos" (GIL, 2002, p.42). É notório que a palavra "determinar" é muito forte e os objetivos do trabalho são bem mais modestos. De modo contrário, pelo presente trabalho tentar-se-á contribuir para o debate a partir da explicação de alguns dos condicionantes que mais possam contribuir para a ocorrência ou não do processo de desindustrialização.

\subsection{DADOS}

$\mathrm{Na}$ pesquisa quantitativa, a partir dos dados secundários analisou-se alguns indicadores econômicos evidenciados no referencial teórico como importantes para a verificação de um possível processo de desindustrialização. A partir dos dados secundários extraídos da base de dados do World Bank (2016) foram construídos alguns indicadores, como a participação relativa do valor adicionado da indústria no PIB total (\%) e a participação relativa da indústria de transformação no produto industrial (\%). A unidade de todos esses dados está em dólares de 2005. 
Além disso, extraiu-se também do Banco Mundial o dado referente a participação relativa do emprego industrial no emprego total de todos os países no período analisado pelo artigo.

$\mathrm{Na}$ avaliação da pauta exportadora foram analisadas as participações relativas de quatro grupos de produtos com diferentes níveis de agregação de valor - bens de capital, bens de consumo, bens intermediários e matérias-primas - na pauta de exportação total de cada país selecionado. Os dados foram extraídos do programa World Integrated Trade Solution (WITS, 2016) que permite a extração da base de dados United Nations Commodity Trade Statistics (UN COMTRADE).

Para complemento da análise extraiu-se da base de dados Instituto de Pesquisa Econômica Aplicada (IPEADATA) índices de preços por classificação de produtos disponibilizados pela Fundação Centro de Estudos do Comércio Exterior (Funcex) para verificar uma possível relação entre o aumento ou o descenso destes na variação de determinados tipos de bens na pauta exportadora.

\section{RESULTADOS}

No começo da década de 1990 a América Latina experimentou um incremento do recebimento de capitais e recursos externos, que aumentou o estoque de divisas, pressionando a valorização das taxas de câmbio reais dos países da região. Como efeitos negativos, a balança comercial da região tornou-se deficitária por vários anos (MORDECKI, 2002). Essa década é conhecida pelas sucessivas crises financeiras; a primeira crise, a mexicana causou um baque nas economias em meados da década. (ibidem). No final da década, primeiramente a crise dos países asiáticos, os ataques especulativos e depois a moratória da Rússia trouxeram graves consequências para as economias latino-americanas, com grande volatilidade cambial, fuga de capitais e desvalorizações cambiais.

A crise ao final dos anos de 2000 evidenciava de certa forma as debilidades do modelo neoliberal nas economias latino-americanas. Em resposta aos indicadores sociais, pobreza, desemprego, desigualdade social, debilidades na estrutura produtiva, crises financeiras diversos países adotaram um novo modelo que se caracterizou por se manter o equilíbrio macroeconômico e no balanço de pagamentos com a introdução de políticas que visavam avançar na questão da pobreza e desigualdade dos países e, principalmente, a volta do Estado com controles moderados da economia e do desenvolvimento econômico ${ }^{11}$. Este período representou uma nova etapa de vigoroso crescimento econômico até a crise financeira de

\footnotetext{
${ }^{11}$ Conforme Bresser-Pereira e Theuer (2012) "uma nova esquerda nacionalista" passou a ser eleita na América Latina, como por exemplo, Luiz Inácio Lula da Silva em 2002, e Dilma Rousseff em 2010, na Argentina, com Eduardo Duhalde, em 2002, Néstor Kirchner em 2003 e Cristina Kirchner em 2007 e 2011; no Uruguai Tabaré Vázquez em 2005. E por fim no Paraguai, Fernando Lugo em 2008.
}

DRd - Desenvolvimento Regional em debate (ISSNe 2237-9029)

v. 8 , n. 1, p. $90-117$, jan./jun. 2018. 
2008, a partir de quando as bases desse "novo modelo"12 sofreram os reveses da crise internacional (BUSTOS, 2010; COLOMBINI NETO, 2012).

É notório que desempenhou um papel fundamental nesse processo o aumento dos preços das commodities e baseadas em recursos naturais no mercado internacional, bem como o elevado crescimento da China ("Efeito China"13) e da Índia e de outros países emergentes, elevando a demanda por produtos dos países latino-americanos. (BUSTOS, 2010; COLOMBINI NETO, 2012; PINTO, 2013).

A ampla literatura enfatiza o "boom dos preços das commodities" que teria potencializado a exportação de bens primários na América Latina. Isso pode ser visto na Figura 1.

Figura 1 - Taxas de crescimento dos preços de produtos básicos, manufaturados, bens intermediários e bens de capital.

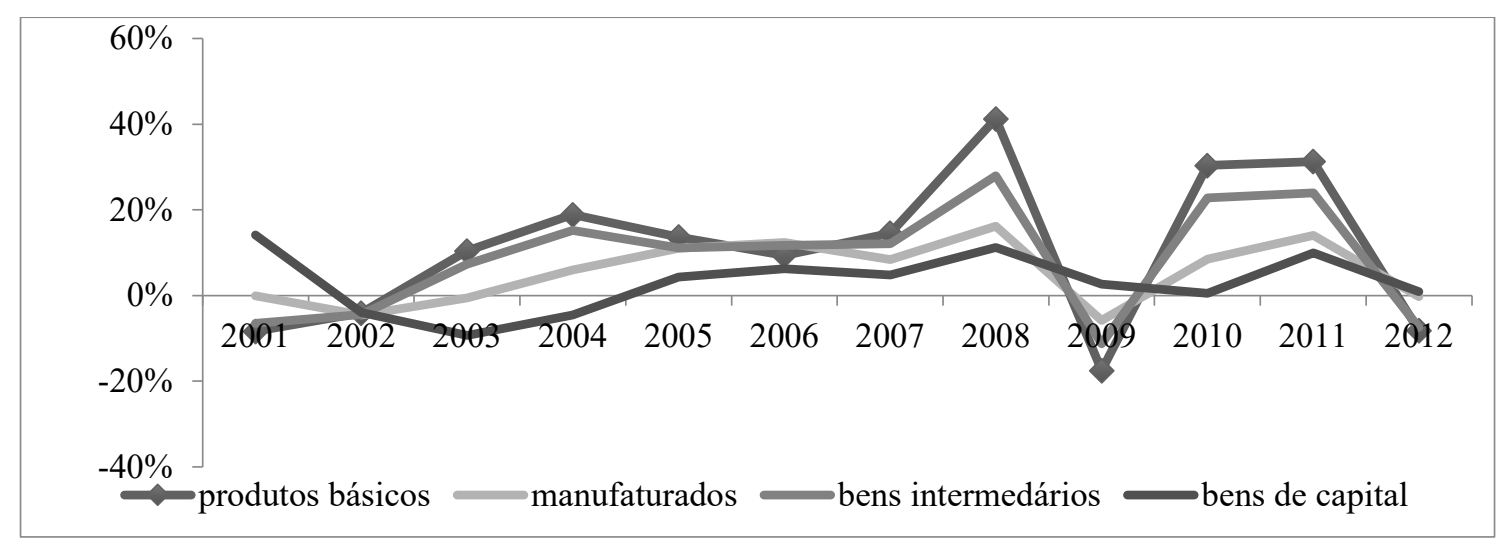

Fonte: Elaboração própria a partir de índices de preços divulgados pela FUNCEX (média 2006=100)

Na década de 1990 sobre a pauta exportadora brasileira, os dados de participação dos bens de capital indicam uma leve expansão enquanto a participação das matérias-primas tendeu a se manter na média, apesar de algumas leves oscilações. Os dados também revelaram com destaque a evolução da participação de produtos primários a partir dos anos 2000 e a tendência de queda da participação dos bens de capital na pauta exportadora a partir de meados da década, conforme Figura 2.

\footnotetext{
12 Este novo modelo é denominado "novo-desenvolvimentista" por Bresser-Pereira (NETO, 2012). No entanto, não é objetivo deste trabalho entrar no debate sobre tal classificação e sim lançar mão das suas características principais.

13 Segundo Medeiros (2006 apud Pinto, 2013, p.11) a China gerou efeitos para economia mundial na forma "duplo pólo", pois "[...] tornou-se o principal produtor e exportador mundial de produtos da Tecnologia da Informação e de bens de consumo intensivo em mão de obra [...] e transformou-se numa exportadora líquida para os Estados Unidos, o Japão e alguns países europeus. Do outro lado, tornou-se grande compradora da produção mundial de máquinas e equipamentos, de produtos de alta tecnologia e de matérias primas (petróleo, minerais, produtos agrícolas etc.)".
} 
Figura 2 - Participação relativa de bens de capital, consumo, intermediários e matérias primas nas exportações Brasil - 1990-2012.

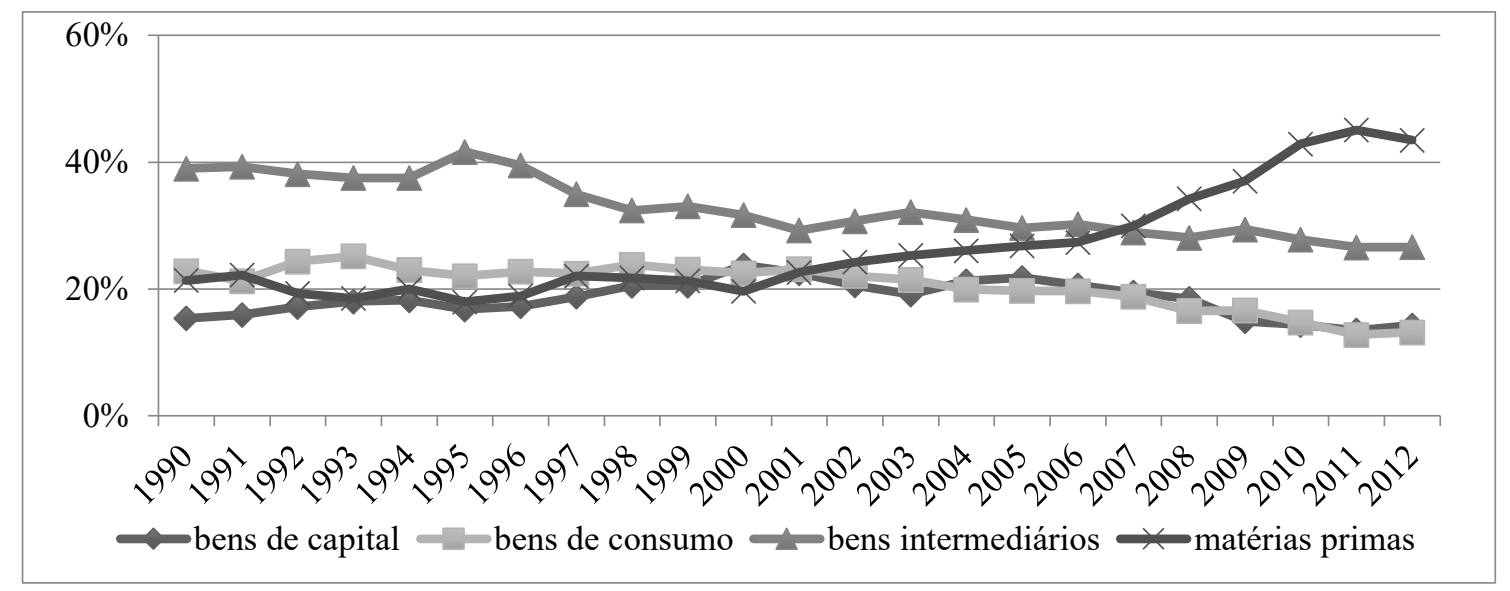

Fonte: Elaboração própria a partir de dados da United Nations Commodity Trade Statistics (UN COMTRADE).

Tais fatos revelados pelos dados corroboram a afirmação de Schwartsman (2009) de que a redução da participação de bens manufaturados na pauta exportadora se deu não pela diminuição da exportação destes, mas pelo aumento das exportações de bens primários devido à elevação dos preços internacionais das commodities; pois, como já salientado, a variação da participação de matérias primas foi mais acentuada (em torno de trinta pontos percentuais) se comparada com a dos outros grupos (em torno de quinze pontos percentuais).

No que diz respeito à participação relativa do valor adicionado da indústria no PIB total, esta apresentou uma tendência de queda leve no período de $28 \%$ para em torno de $25 \%$ no final da década de 1990, já nos anos 2000 a queda persistiu de forma lenta chegando aos últimos anos da série a uma participação de $23 \%$. Quanto à participação relativa da indústria de transformação no produto industrial, manteve-se na maior parte do período, mas apresentou tendência de queda relevante em momentos de crises: entre 1999 e 2000 um recuo de aproximadamente $6 \%$ e entre 2008 e 2012 houve um recuo de aproximadamente 5\%, conforme Figura 3. 
Figura 3 - Participação relativa do valor adicionado da indústria no PIB total (\%) e participação relativa da indústria de transformação no produto industrial (\%) - Brasil - 1990-2012.

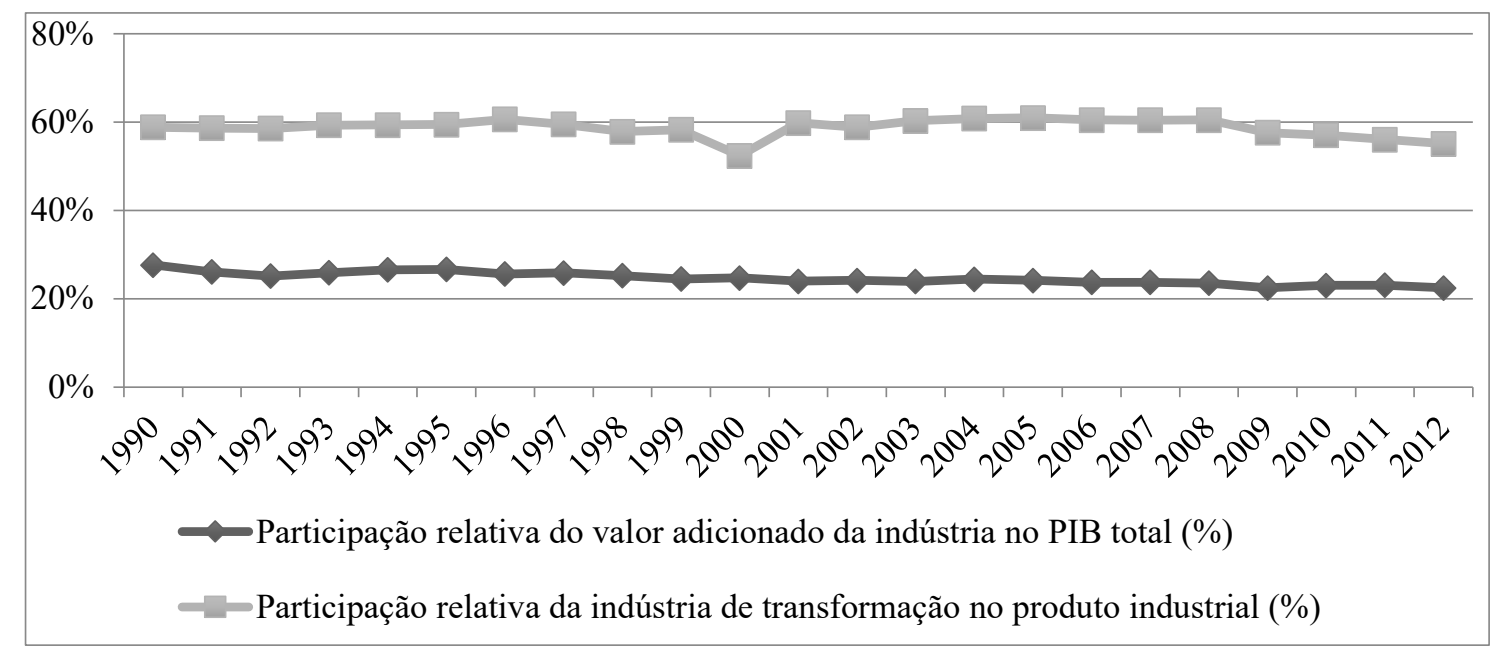

Fonte: Elaboração própria a partir de dados do World Bank (2016)

Mercadante (1998 apud WASQUES; TRINTIN, op. cit) aponta que após 1994 o ritmo de crescimento da indústria de transformação brasileira se desacelera devido à combinação de política cambial (âncora cambial) e monetária, pois assim criou-se um estímulo à importação prejudicando a indústria nacional.

Ainda segundo Wasques e Trintin (op. cit.), em 1998 e nos anos seguintes, a indústria de transformação continuou a apresentar queda no crescimento, o que, segundo os autores, se deveu à

liberalização comercial, sobrevalorização cambial, elevadas taxas de juros e os efeitos dos intensos choques internacionais sobre a economia brasileira, que culminaram com a mudança do regime cambial, com forte desvalorização do Real e severo aperto monetário no primeiro semestre de 1999. (Ibidem, p. 9)

Conforme a figura $4^{14}$, a participação relativa do emprego industrial no emprego total também apresentou uma mudança pequena, variando entre $19,2 \%$ e $22 \%$ ao longo do período; apresentando tendência à queda entre 1995 e 1999 e, a partir de 2000, com exceção dos anos de 2009 e 2011 , a tendência apresentada foi de crescimento.

Segundo Ilha \& Rubin (2001), um dos efeitos imediatos do Plano Real sentido já um ano após sua implantação foi a redução do desemprego, o que explicaria o ponto de inflexão em 1995.

${ }^{14}$ Os dados para os anos de 1991 e 1994 não estavam disponíveis. 
Figura 4 - Participação relativa do emprego industrial no emprego total (\%)- Brasil - 1990-2012.

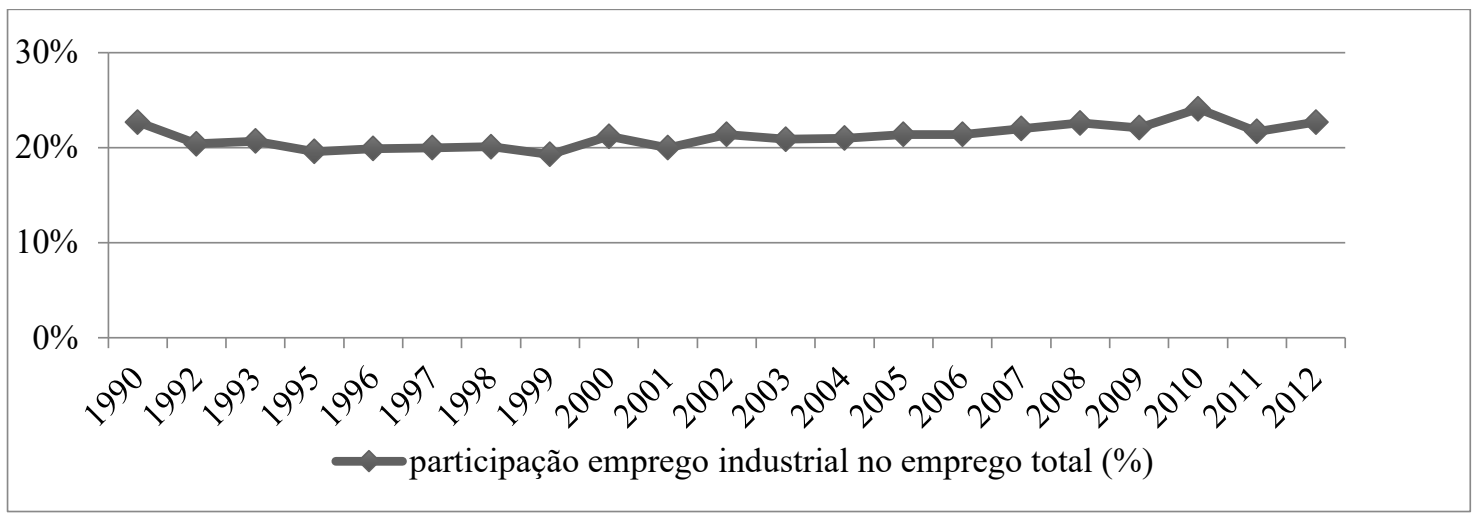

Fonte: Elaboração própria a partir de dados do World Bank (op.cit).

Em suma, durante todo o período, atravessando as décadas de 1990 e 2000, a participação da indústria no PIB tem leve e persistente queda. Na década de 1990 as participações da indústria de transformação no produto industrial e do emprego industrial no emprego total se mantêm, contudo de 2003 a 2008 há alguma reversão desses dois indicadores, pois essas relações elevam-se timidamente. Tendo esses indicadores em vista, apenas a participação da indústria do PIB sugere desindustrialização, enquanto os outros dois não vão ao mesmo sentido.

Na década de 1990 não se pode dizer que houve reprimarização de exportações, a participação das matérias-primas mantiveram em torno de uma média e as de bens de capital expandiram-se levemente. Por outro lado, os dados sugerem o processo de "reprimarização da pauta de exportações" a partir de 2000, porque bens primários ganharam participação enquanto as dos bens de capital e consumo declinaram.

De modo singular, entre 2008 e 2012 a participação da indústria de transformação no PIB industrial sofre uma abrupta queda de mais de $5 \%$ e houve uma continuidade da reprimarização da pauta de exportações iniciada na década de 2000.

A Argentina, junto com o Brasil, gestou a criação do Mercosul através do Programa de Integração e Cooperação de 1986 e pelo projeto de um mercado comum bilateral, pelo Tratado de Integração em 1988. A Argentina passou pela experiência de um plano de estabilização no início da década de 1990, amparado no câmbio sobrevalorizado e a introdução de reformas mais liberalizantes. A profunda crise financeira, quando da ocasião da moratória da dívida externa em 2001 deixou marcas, que possibilitaram uma certa variação do "modelo" de políticas econômicas em busca do crescimento econômico pela industrialização.

De acordo com Mordecki (2002) a inflação da Argentina esteve acima de 1000\% no ano de 1990, por isso no princípio de 1991 houve a criação do Plano de Convertibilidade ${ }^{15}$, que visava atacar as expectativas inflacionárias dos agentes econômicos, com a principal

\footnotetext{
${ }^{15}$ No que tange a inflação, o Plano de Convertibilidade obteve um êxito notável, pois esta diminuiu de $1343,9 \%$ em 1990 para 3,9\% em 1994 e manteve a estabilidade monetária nos próximos anos (GANTMAN, op.cit, p.338).
}

DRd - Desenvolvimento Regional em debate (ISSNe 2237-9029)

v. 8 , n. 1, p. $90-117$, jan./jun. 2018. 
medida de atrelamento da moeda local ao dólar (ILHA; RUBIN, 2001; GANTMAN, 2012; MORDECKI, 2002).

Gantman (2012) enfatiza que como proposta aliada ao plano anti-inflacionário, implementou-se uma série de reformas liberalizantes como a abertura indiscriminada ao exterior, paulatina redução da presença do Estado na produção direta de bens e serviços. $\mathrm{O}$ autor aponta que essas mudanças tiveram um importante impacto em diversos setores da indústria e da economia. Como exemplo o autor cita que a sobrevalorização cambial induziu a quebra das pequenas e médias empresas intensivas em mão de obra contribuindo para o aumento do desemprego (ibidem, 2012)

Neste contexto, de 1990 a 1994 a participação relativa da indústria no PIB se manteve estável a cerca de 31,5\%. O emprego industrial no emprego total e o valor adicionado da indústria de transformação no produto industrial se reduziram respectivamente em pouco mais de 3\% (Figura 5). Já entre 1995-2002, houve uma relativa manutenção da participação indústria no PIB, mas a indústria de transformação no produto industrial deteriorou 3\% (WOLD BANK, 2016).

No período posterior ao episódio da turbulência financeira ocasionada pela crise mexicana (1994) nos mercados financeiros internacionais, entre 1995 e 2002, a participação do emprego industrial no emprego total sofreu uma significante redução de aproximadamente $6,8 \%$ (Figura 6). A crise mexicana foi o primeiro sintoma da vulnerabilidade externa da economia argentina, que seria confirmada pelas outras crises financeiras do restante da década, decorrente da estratégia de uso do câmbio para estabilização da inflação. Essa vulnerabilidade refere-se à dependência da entrada de capitais externos para financiamento das importações e dos déficits em conta corrente, num contexto de incerteza nos mercados financeiros globais, e também da parte dos capitais estrangeiros na forma investimentos estrangeiros diretos (importantes para o crescimento econômico). Nesse contexto de turbulência financeira, segundo os dados do World Bank (2018) a taxa de crescimento média do PIB que foi de 6,79\% entre 1990-1994, decresceu para uma média -6,04\% entre 1995 e 2002. Subdividindo-se esse período, entre 1995 e 1999 este indicador foi de 2,25\%, já entre 1999 e 2002 de $-5,36 \%$. O vigor do decrescimento do PIB pode ser elencado como explicação do aumento do desemprego na economia.

A forte diminuição do emprego no setor industrial pode ser explicado pela sobrevalorização cambial e as privatizações. As privatizações incentivaram a substituição de mão de obra manual por capital através da modernização de máquinas e equipamentos (BEKER, 1998 apud GANTMAN, 2012) e a alteração de plantas de negócios. Segundo Gantman (2012) isto contribuiu para as elevadas taxas de desemprego registradas no período.

Consoante a isso, a modernização e o aumento da produtividade podem explicar o amortecimento na estagnação da participação da indústria no PIB e da menor queda da indústria de transformação em comparação a elevada queda registrada no que tange à participação do emprego industrial. 
Figura 5 - Participação relativa do valor adicionado da indústria no PIB total (\%) e participação relativa da indústria de transformação no produto industrial (\%) - Argentina - 1990-2012.

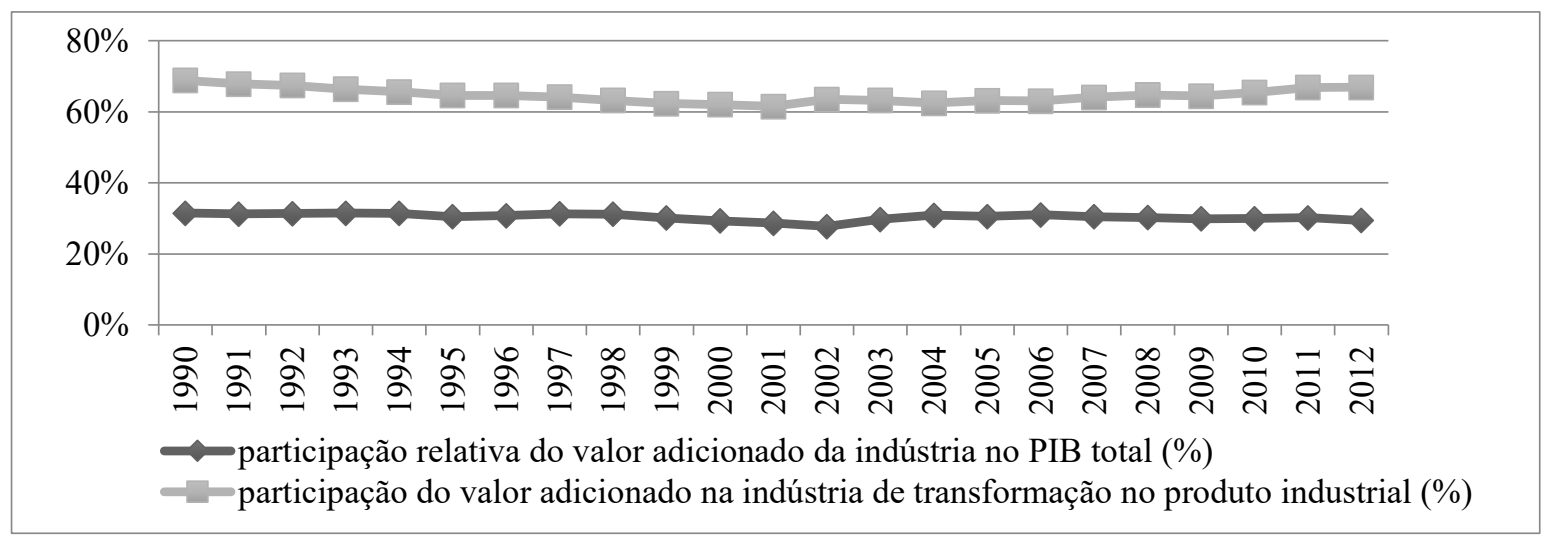

Fonte: Elaboração própria a partir de dados do World Bank (2016).

O contexto econômico argentino pós-2003 é interpretado por Colombini Neto (2012) como um nítido caso da adoção do modelo "novo-desenvolvimentista". Assim, no período de 2003 a 2008, em função da recuperação da economia argentina, os indicadores analisados melhoraram levemente, ou no caso na participação do valor adicionado da indústria no PIB manteve-se (COLOMBINI NETO, op.cit). No caso do emprego o autor assinala que os postos de trabalho passaram a ser desenvolvidos sob uma maior proteção social, diminuição da abertura comercial e das privatizações (COLOMBINI NETO, 2012).

Figura 6 - Participação relativa do emprego industrial no emprego total - Argentina - 1990-2012

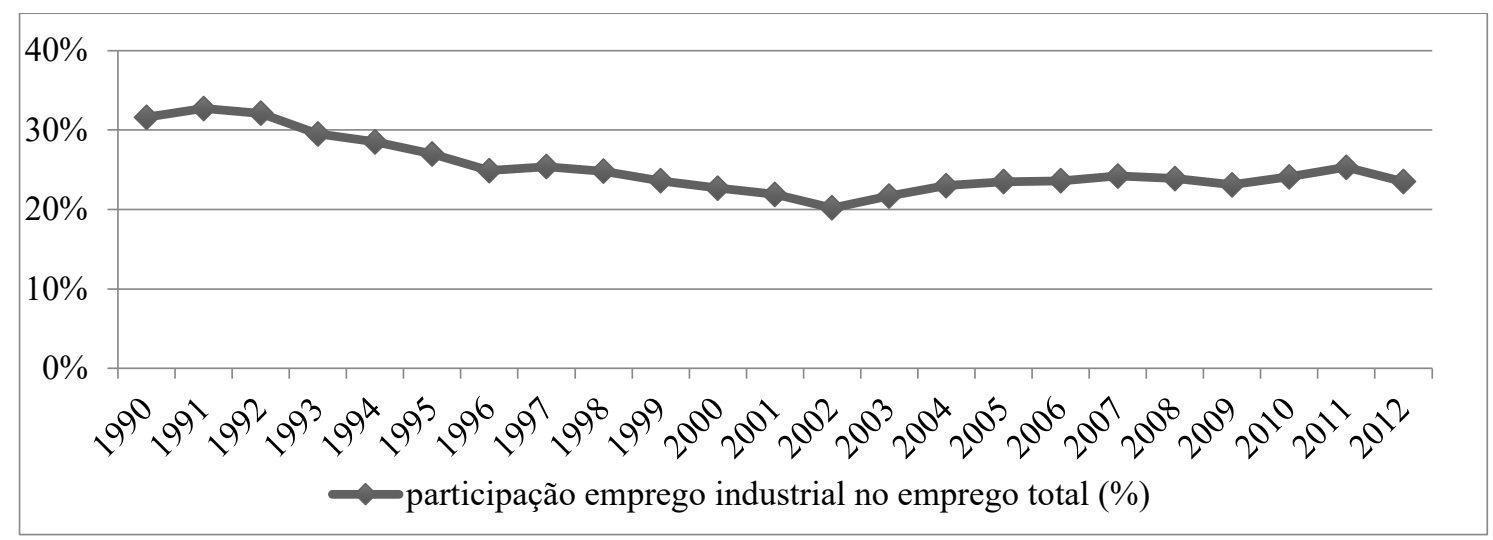

Fonte: Elaboração própria a partir de dados do World Bank (2016).

Para Colombini Neto (2012), o avanço da industrialização na Argentina não se deve a grandes políticas de promoção industrial impulsionadas pelo Estado argentino e que significaria a volta dos esforços do PSI. Na verdade, "as políticas governamentais obtiveram um enfoque agroindustrial, com uma aliança das grandes lideranças agrárias e do governo, buscando também uma promoção industrial." (ibidem, s.d). 
Para o período de 2008 a 2012, percebemos uma variação na participação relativa da indústria no PIB, do emprego industrial no PIB e do valor adicionado da indústria de transformação no produto industrial. A participação do emprego industrial no PIB se encontrava em 64,76\% em 2008, já no ano de 2012 elevou-se para 66,93\%.

Houve regressão da participação dos bens primários na pauta exportadora argentina, consoante a um aumento maior na participação dos bens intermediários. O destaque é que os bens de capital e os bens de consumo (até 2006) de forma geral aumentaram suas participações, de forma maior após 2003, conforme Figura 7.

Figura $7^{16}$ - Participação relativa de bens de capital, consumo, intermediários e matérias primas nas exportações - Argentina - 1993-2012.

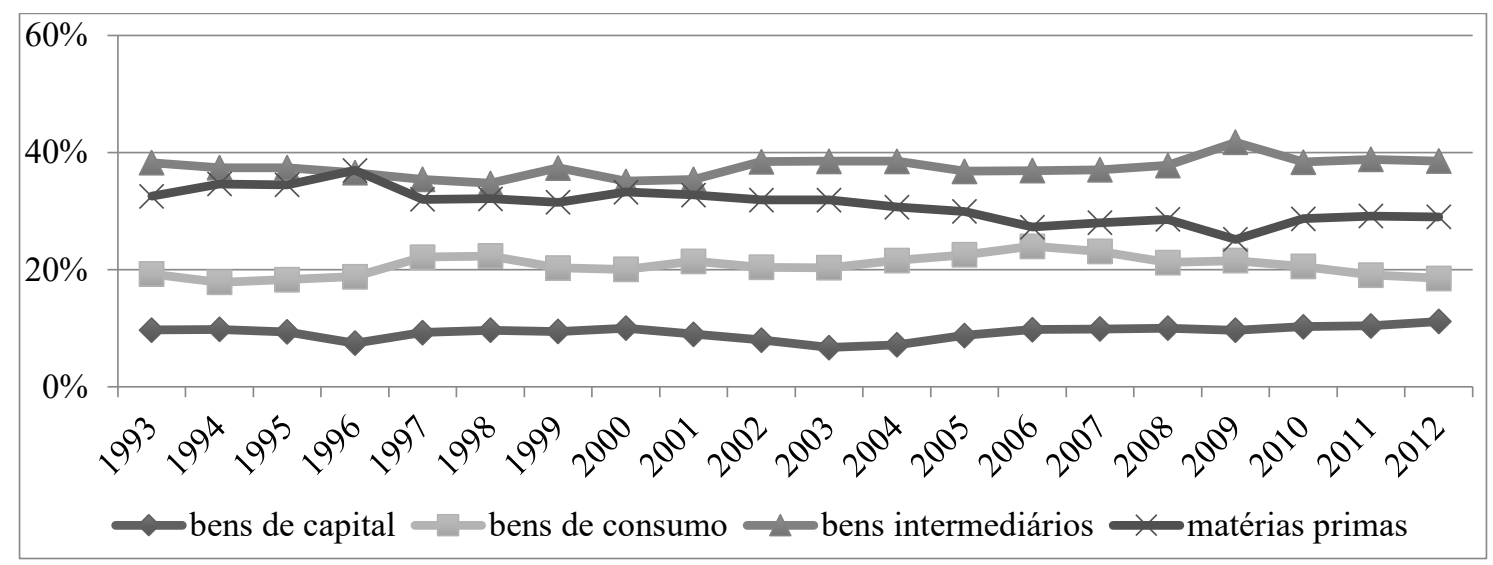

Fonte: Elaboração própria a partir de dados da United Nations Commodity Trade Statistics (UN COMTRADE, 2016).

Resumidamente, na década de 1990 apesar da manutenção da participação do valor adicionado da indústria no PIB, há indícios da ocorrência do processo de desindustrialização pela significativa perda das participações da indústria de transformação e do emprego industrial, respectivamente no produto industrial e no emprego total; mas não da reprimarização da pauta de exportações, pois de maneira geral a composição da pauta de exportações permaneceu a mesma, mas com uma redução da participação das exportações de matérias-primas. Já os dados da economia argentina pós-2003 sugerem que o processo de desindustrialização não continuou ocorrendo, pois a participação da indústria no PIB permaneceu estabilizada e a participação do emprego gerado na indústria no emprego total e a participação da indústria de transformação no produto industrial cresceram. No tocante a pauta de exportações, houve uma redução da participação das matérias-primas na pauta exportadora e um leve aumento da categoria de bens intermediários, o que indica que não houve um evidente processo de reprimarização das exportações.

O Uruguai, um dos países que se juntou a Brasil e Argentina para composição do Mercosul também passou pela dinâmica de reformas liberais, embora em menor intensidade, e um plano econômico visando o estancamento do processo inflacionário também ocorreu. No

${ }^{16}$ No intervalo de 1990 a 1992 os dados não estavam disponíveis. 
entanto no período posterior, a partir de 2005 a economia uruguaia passou por algumas modificações de política econômica e mudanças institucionais que possibilitaram o fortalecimento econômico do país.

Na redemocratização uruguaia em meados da década de 1980, a economia do país experimentou a aceleração inflacionária e o aumento do déficit fiscal alcançando $130 \%$ ao final do período. Desta forma, no segundo governo democrático o país passou por um plano de estabilização econômica, concomitante às reformas liberalizante e a Reforma do Estado (MORDECKI, 2002). Este processo se propagou durante toda década e as medidas estavam inscritas no âmbito das medidas do Consenso de Washington ${ }^{17}$.

Resumidamente,

Una vez que la inflación bajó de los dos dígitos, el gobierno trató de atender el problema del 'atraso cambiario' generado por el plan de estabilización aplicado. De esta forma, a fines de la década, en el bienio 1999-2000, la política de corto plazo trató de conciliar dos objetivos: la me-jora de la competitividad y la preservación de la estabilidad (ANTÍA, 2001, p.47).

No final do primeiro ano, foi adotada a âncora cambial como parte de um novo plano de estabilização anti-inflacionário. A abertura da economia e o ingresso de capitais sustentou a âncora. Desta forma, esperava-se que "[...] asegurado el equilibrio fiscal, la variación de los precios de los bienes transables iba a converger con la tasa de devaluación más la inflación internacional", excedendo a convergencia aos bens não comercializáveis. (MORDECKI, 2002, p.15).

Em meio a essas transformações em matéria macroeconômica entre 1990 e 2003, e mais propriamente à estabilização, verifica-se a perda de aproximadamente 7 pontos percentuais na participação relativa do valor adicionado da indústria no PIB total. Já a participação da indústria de transformação no produto industrial e o emprego industrial como proporção do emprego total deterioram-se, respectivamente aproximadamente 9 e 10,5 pontos percentuais (Figuras 8 e 9). Esses dados sugerem a ocorrência do processo de desindustrialização na década neste período.

\footnotetext{
${ }^{17}$ No caso uruguaio as privatizações sofreram grande resistência. Dessa forma o país passou por um processo menor que de outros países da América Latina. (BITTENCOURT, 2009; MORDECKI, 2002). A lei original que esboçava um plano de privatizações foi derrubada em 1992 por um plebiscito e, em razão disso, privatizaram-se só algumas poucas empresas - PLUNA e Companhia de gás. Diante disso, os subsequentes governos adotaram medidas que flexibilizassem e permitissem a entrada de empresas privadas em alguns setores e atividades. (MORDECKI, 2002)
} 
Figura 8 - Participação relativa do valor adicionado da indústria no PIB total (\%) participação relativa da indústria de transformação no produto industrial (\%) - Uruguai - 1990-2012

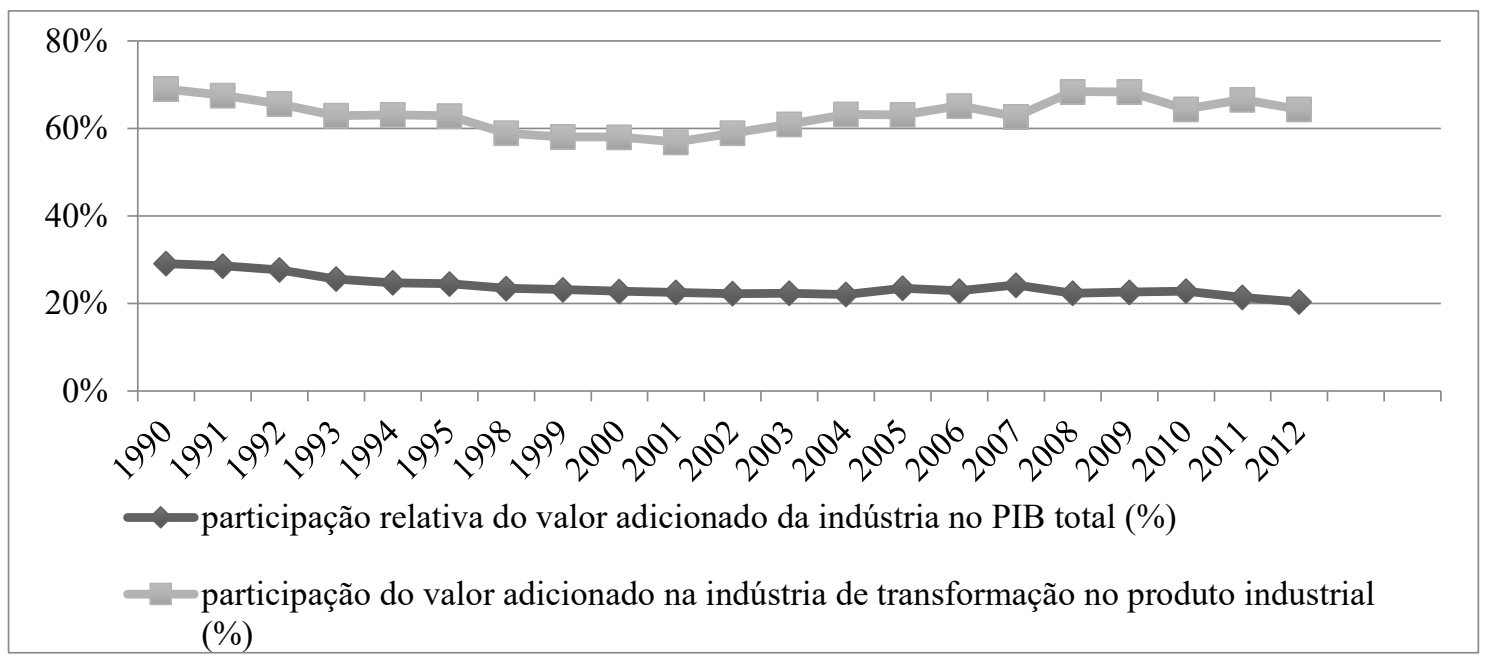

Fonte: Elaboração própria a partir de dados do World Bank (2016).

$\mathrm{Na}$ literatura consultada, precisamente em Antía (2001) e Mordecki (2002), é consenso que na década de 1990 o Uruguai se inseriu no mercado internacional através da abertura unilateral e no âmbito regional com a experiência do Mercosul e realizando acordos com outros países vizinhos como Chile em 1996 e Bolívia em 1997. Os autores enfatizam que num primeiro momento apesar da âncora cambial adotada no Uruguai, os produtos uruguaios não sofreram perda de competitividade em relação ao Brasil e Argentina, porque esses países também mantiveram estratégias de estabilização similar à implementada no Uruguai.

Figura $9^{\mathbf{1 8}}$ - Participação relativa do emprego industrial no emprego total - Uruguai - 1990-2012.

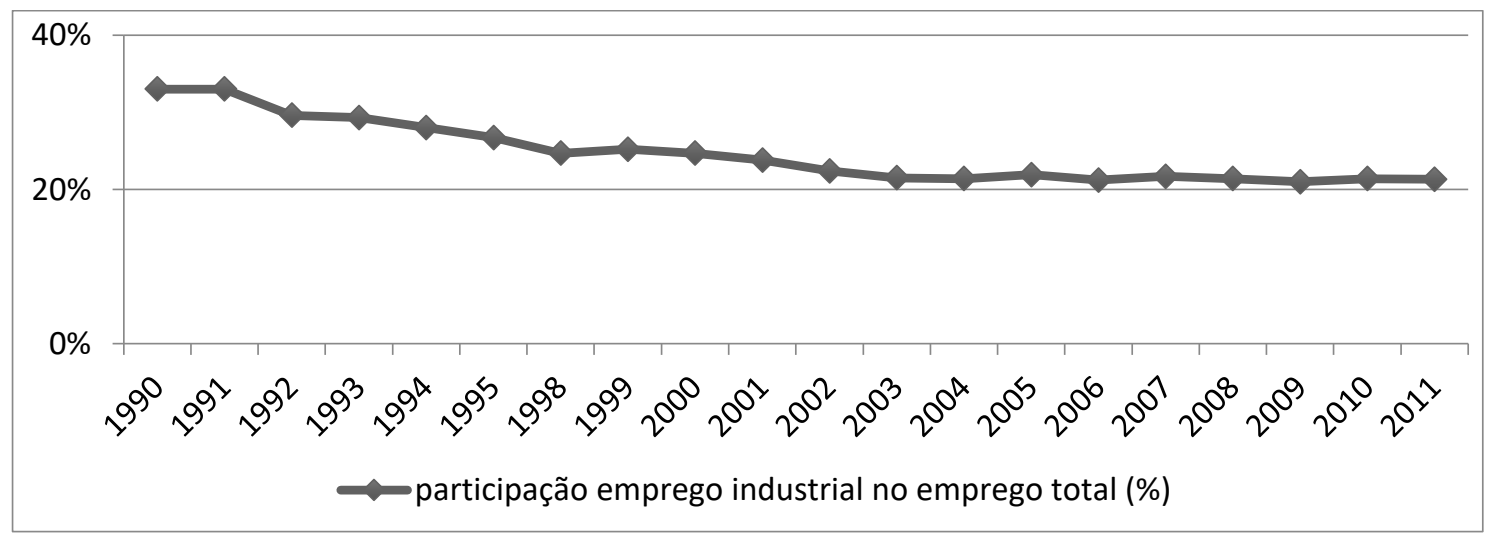

Fonte: Elaboração própria a partir dos dados oriundos do World Bank (2016)

Após as desvalorizações do Brasil em 1999 e da Argentina em 2002 a situação ficou insustentável em termos comerciais e de competitividade, obrigando as autoridades do

18 O dado para 2012 não estava disponível. 
Uruguai a aumentarem o ritmo de desvalorização e a banda cambial e por fim adotarem a livre flutuação do câmbio ${ }^{19}$.

Apesar de reconhecer a importância do incremento comercial com Argentina e Brasil, Bittencourt (2009) adverte que a economia uruguaia não obteve uma inserção comercial com o resto do mundo e que os investimentos estrangeiros diretos e a própria integração regional não beneficiou tanto a economia uruguaia.

[...] La década de los 90, período de fuerte desindustrialización en Uruguay, favoreció a las actividades de servicios y de carácter regional, con una ecuación cambiaria favorable en el intercambio con Argentina y Brasil pero no con el resto del mundo. En este período la IED reforzó ese esquema de desindustrialización ya que el "efecto MERCOSUR" provocó que varias multinacionales que realizaban procesos de valor agregado en Uruguay se localizaran en los vecinos mayores (economías de escala en la producción) y,sin barreras arancelarias, convirtieran a su filial uruguaya en una distribuidora [...] (BITTENCOURT, 2009, p.18-19).

A partir de 2005 o governo eleito no Uruguai, sob a presidência de Tabaré Vázquez instituiu uma série de transformações econômicas, sociais e institucionais. Para Lorenzo (2010) a estratégica básica do governo foi o manejo consciente e cuidadoso das variáveis de política econômica e outras reformas institucionais, assegurando credibilidade e estabilidade, aliada a expansão de um sistema de políticas sociais ${ }^{20}$.

A política de câmbio flexível continuou e tem sido implementado o sistema de metas de inflação, cuja inflação deve variar entre 3\% e 7\% (LORENZO, 2010).

Lorenzo (2010) considera que os anos antedecentes a crise de 2008 serviram para a reestruturação da economia uruguaia e reduzir as vulnerabilidades dessa economia. O que se poderia verificar no melhor desempenho da economia uruguaia.

As políticas econômicas na crise de 2008 privilegiaram investimentos que produziriam mais e com potencial capacidade de geração de emprego e exportações, além de medidas para setores específicos; viabilizando projetos de investimento através de crédito e incentivos ao desenvolvimento de inovação. "Finalmente, como forma de contribuir a la reducción de costos de las empresas, se habilitó la deducción del IVA del gas oil utilizado por empresas industriales" (LORENZO, 2010, p.184).

A partir da desvalorização cambial de 2002 as participações do valor adicionado da indústria no PIB - após um salto em 2002 e 2003 - e do emprego industrial no emprego total se mantiveram relativamente estagnados até o fim da série. De modo contrário, no mesmo período, a participação da indústria de transformação obteve um crescimento da participação no PIB industrial de aproximadamente de 9,5 pontos percentuais, chegando a 2009 ao nível de

\footnotetext{
19 Neste período a economia uruguaia começou a deteriorar-se pelo aumento da saída de capitais, perda de reservas internacionais e a profunda crise fiscal do Estado (MORDECKI, 2002). A retração do PIB foi de $12,99 \%$ entre 1999 e 2002.

20 A situação econômica e social herdada pelo novo governo foi de consideráveis problemas sociais, por exemplo, em 2004 a pobreza alcançava $32 \%$ e a taxa de desemprego estava aproximadamente do nível de $13 \%$. (LORENZO, 2010, p.149). Este autor também destaca que ademais o endividamento público restringia os gastos do governo, que tinha serviços financeiros a arcar no curto prazo e restringia a elevação das políticas públicas e sociais, e foi preciso firmar acordos com o Banco Mundial, FMI, BID para assegurar a credibilidade financeira.
}

DRd - Desenvolvimento Regional em debate (ISSNe 2237-9029)

v. 8, n. 1, p. 90-117, jan./jun. 2018. 
$68,44 \%$, próximo do nível que se encontrava em 1992. A adoção das políticas contra a crise não surtiram notáveis efeitos para o crescimento dos indicadores, mas assim mesmo pode ter contribuído para um desvio não muito grande da trajetória que já vinham apresentando, evitando uma queda acentuada (Figuras 8 e 9). Desta forma, se até 2003 o processo de desindustrialização foi verificado, pode-se dizer que pelos dados apresentados houve certo recuo desse processo em meio ao novo manejo das políticas econômicas e reformas institucionais.

$\mathrm{Na}$ pauta exportadora uruguaia na década de 2000, o destaque de crescimento do período é dos bens primários, a participação desses bens na pauta exportadora deu um salto de aproximadamente 33,45\% em 2002 para 46,7\% em 2008. Os bens de capital e de consumo experimentaram um leve aumento das suas respectivas participações (Figura 10).

Usando classificações diferentes, alguns autores demonstram o elevado crescimento desses produtos na pauta de exportação. "Las exportaciones del sector agropecuario/agroindustrial con ventajas comparativas reveladas representan una fracción creciente de las exportaciones de bienes y servicios, la cual pasa de 55-60\% en 1985 para más del75\% en 2011". (URUGUAY, 2011 apud PAOLINO; BONELLI, 2012, p.180).

Figura $10^{\mathbf{2 1}}$ - Participação relativa de bens de capital, consumo, intermediários e matérias primas nas exportações - Uruguai - 1990-2012.

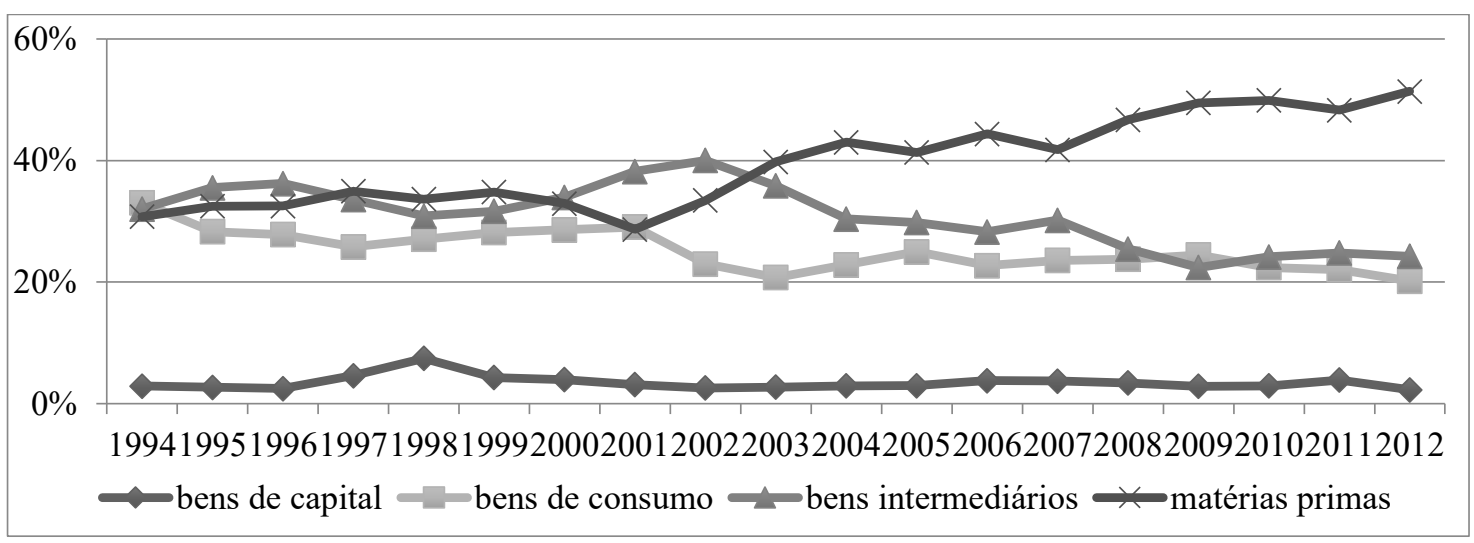

Fonte: Elaboração própria a partir de dados da United Nations Commodity Trade Statistics (UN COMTRADE, 2016).

Os dados sobre a economia Uruguaia apontam para a caracterização do processo de desindustrialização na década de 1990 até 2005, além disso não foi possível verificar a reprimarização da pauta de exportações pois as participações das diferentes classificações se mantiveram estáveis. Após 2005 pode-se sugerir que houve algum recuo do processo, além das relações emprego industrial/emprego total e indústria/PIB manterem-se constante (pararam de cair), a indústria transformação alavancou sua participação no produto industrial, retornando a um nível próximo que se encontrava em 1992. Além disso, os bens primários elevaram sua participação notavelmente neste período, o que sugere o fenômeno da reprimarização da pauta exportadora.

${ }^{21}$ Os dados não estavam disponíveis no intervalo de 1990 a 1993. 
O Paraguai é o quarto país a constituir o Mercosul. A economia paraguaia, apesar de inúmeros problemas que enfrenta e seu menor nível de desenvolvimento não deixa de ser importante para a integração regional pretendida através do Mercosul. De acordo com dados do ano de 2008 do MDIC (Ministério do Desenvolvimento, Indústria e Comércio Exterior), o PIB do Paraguai foi estimado em US\$ 12 bilhões a preços correntes. No ano anterior, a economia paraguaia apresentou crescimento de $6,4 \%$ (MDIC, 2008).

O Paraguai experimentou certo progresso econômico a partir do governo Alfredo Stroessner (1954-1989), que alinhou estratégias de desenvolvimento à ideários nacionalistas. Os pontos crucias dessa estratégia, caracterizavam-se por um esforço no sentido de incrementar as exportações, fortalecer a agroindústria e implantar a substituição de importações (mesma estratégia usada no Brasil).

Percebe-se então o papel primordial exercido pelo setor de exportações no crescimento econômico do Paraguai, que durante muito tempo serviu apenas como terras exploradas pelos colonizadores, além de ter sido palco de vários conflitos. De acordo com Paraguay (2007):

Entre los años 2003 y 2006, el sector industrial paraguayo mostró un crecimiento promedio del 2,9\%. Las exportaciones manufactureras por su parte crecieron al $11,4 \%$ entre 2000 y 2005. Durante ese período, los productos más destacados fueron los de media y alta tecnología, cuyas exportaciones crecieron al $33 \%$ y al $26 \%$, respectivamente (PARAGUAY, 2007, p.5).

Apesar destes resultados positivos, deve-se ressaltar que o quantum das exportações de matérias primas é o mais incorporado. Além da soja, produto de maior destaque na pauta exportadora, destaca-se também as vendas de carne no mercado internacional (PARAGUAY, 2007).

Figura $11^{\mathbf{2 2}}$ - Participação relativa do valor adicionado da indústria no PIB total (1990-2012) (\%) participação relativa da indústria de transformação no produto industrial (2005-2012) (\%) - Paraguai.

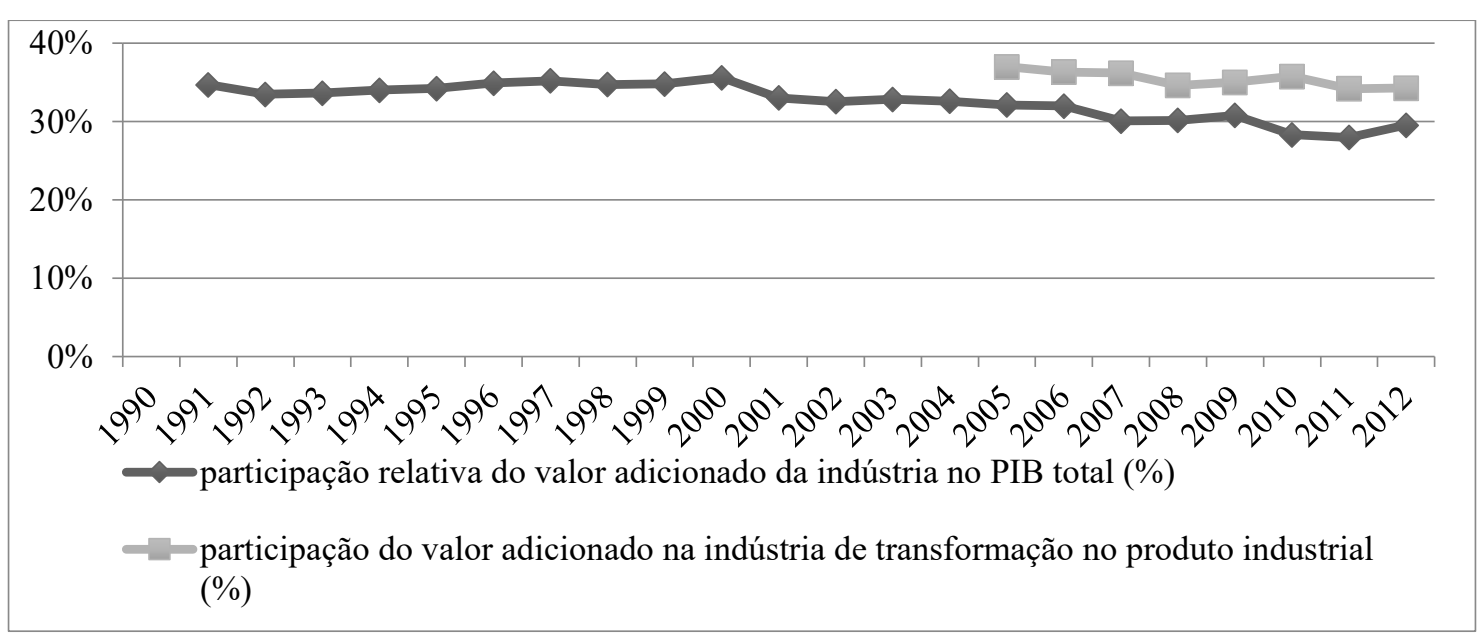

Fonte: Elaboração própria a partir dos dados extraídos do World Bank (2016)

22 Os dados relativos à participação relativa da indústria de transformação no produto industrial não estavam disponíveis para os anos de 1990 a 2004 e os relativos à participação relativa do valor adicionado da indústria no PIB total não estavam para o ano de 1990.

DRd - Desenvolvimento Regional em debate (ISSNe 2237-9029)

v. 8 , n. 1 , p. $90-117$, jan./jun. 2018 . 
Na década de 1990 a participação da indústria no PIB se manteve relativamente estável, porém entre 2000 e 2003 perdeu cerca de 3 pontos percentuais. Já a participação do emprego industrial, que em 1990 era de 27,60\%, apresentou queda de 12,30 pontos percentuais até $2002^{23}$. (Figura 12). Estes resultados podem ser explicados em parte pela adoção das reformas liberalizantes, que proporcionou ganhos de produtividade na indústria, ao mesmo tempo que a inclusão de novas maquinas e técnicas produtivas reduziram o emprego no setor.

Figura $12^{24}$ - Participação relativa do emprego industrial no emprego total - Paraguai - 1990-2012.

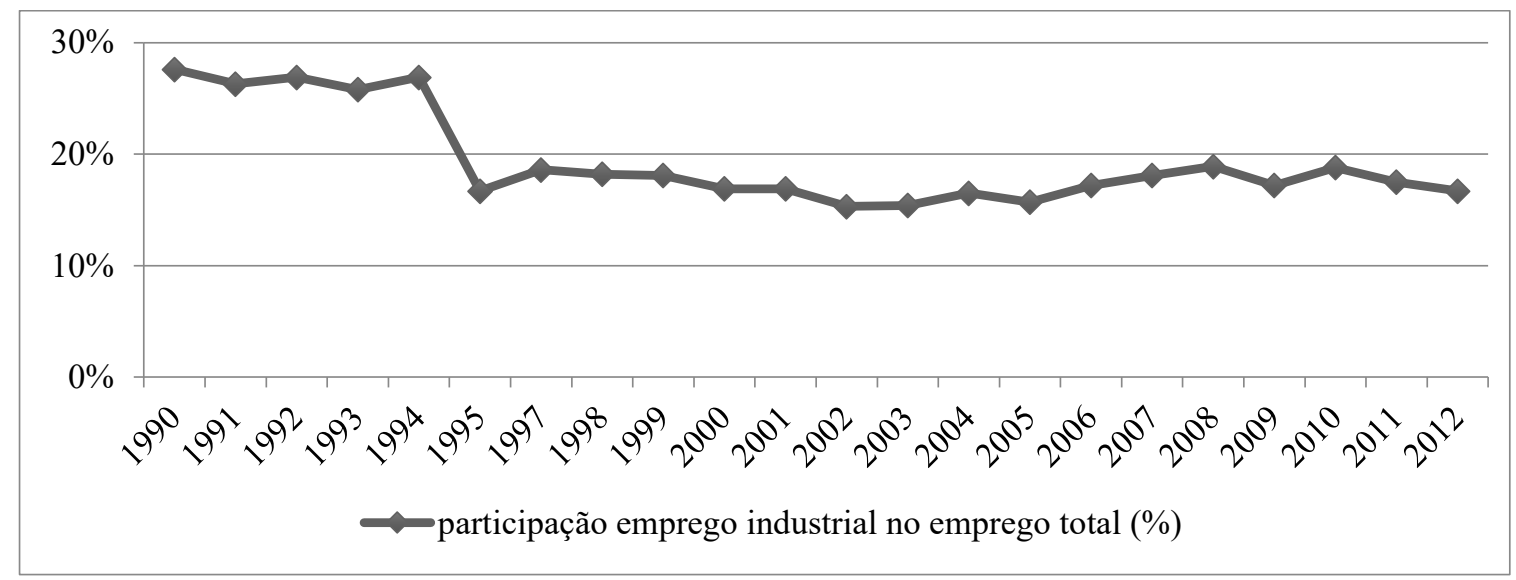

Fonte: Elaboração própria a partir de dados do World Bank (2016).

Entre 2003 e 2008 a participação da indústria no PIB deteriorou-se em 2,70\% ao passo que a participação do emprego industrial em relação ao emprego total avançou 3,50 pontos percentuais. No mesmo sentido, a indústria de transformação retrocedeu sua participação em 2,37 pontos percentuais entre 2005 e 2012 (Figura 11). Especialmente após a crise de 2008, todos os indicadores se deterioraram.

Na pauta exportadora paraguaia, percebe-se que as matérias-primas declinaram sua participação durante o período, e os bens intermediários se elevaram (Figura 13).

\footnotetext{
${ }^{23}$ Não estão disponíveis dados relativos a participação da indústria de transformação no produto industrial no período de 1990-2005 no Paraguai.

${ }^{24} \mathrm{O}$ dado para o ano de 1996 não estava disponível.
} 
Figura 13 - Participação relativa de bens de capital, consumo, intermediários e matérias primas nas exportações - Paraguai - 1990-2012.

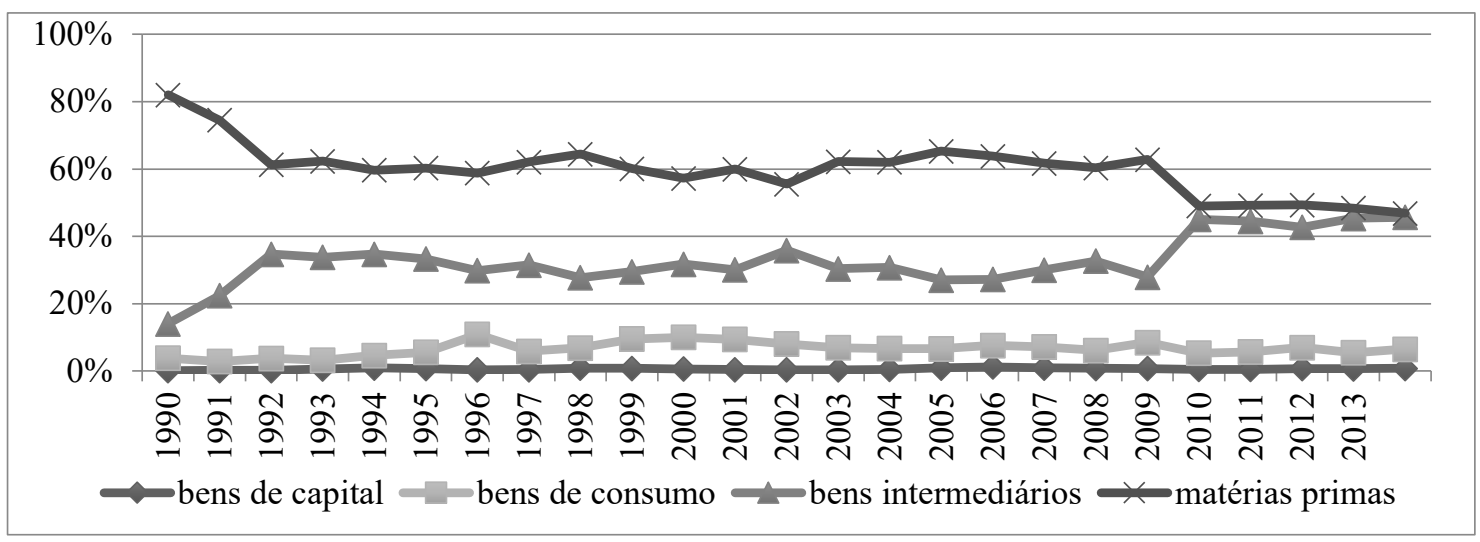

Fonte: Elaboração própria a partir de dados do United Nations Commodity Trade Statistics (UN COMTRADE, 2016).

Não se pode afirmar que houve desindustrialização no Paraguai. Na década de 1990 a participação do valor adicionado da indústria no PIB tendeu a pequenos incrementos, o emprego sofreu abrupta queda na metade da década, mas se manteve estável e não há os dados necessários para todo o período sobre a participação da indústria de transformação no PIB industrial, o que dificulta a análise.

Na década de 2000 observa-se a queda contínua da participação da indústria no PIB, e isso é complementado com a queda também na indústria de transformação no PIB industrial. Isso poderia representar algum indício, porém a participação no emprego industrial no emprego total aumenta, seguindo uma inconclusão. Não houve significativa mudança na pauta exportadora paraguaia. As trajetórias das diferentes classificações de produtos mantiveram-se.

Tendo uma perspectiva global da análise do Mercosul, alguns resultados podem ser sumarizados.

No Brasil, apesar das políticas econômicas visando a estabilização inflacionária e a restrição externa decorrente desta, durante todo o período não verificou-se a ocorrência do processo de desindustrialização e a reprimarização da pauta de exportações é um fenômeno iniciado na década de 2000.

Na Argentina, a conjugação da abertura comercial, câmbio sobrevalorizado e as medidas de ajuste fiscal e as mudanças da estrutura produtiva em decorrência da reestruturação financeira das empresas, estabeleceram um ambiente altamente hostil para a indústria, e propiciou a ocorrência do processo de desindustrialização na economia argentina, mas os dados da pauta de exportações não permitem relacionar a desindustrialização à reprimarização da pauta de exportações neste período. Após a crise da dívida externa com repercussões na credibilidade institucional e dos organismos financeiros internacionais, houve um recuo do processo de desindustrialização devido a novas mudanças na gestão macroeconômica e social, com um maior engajamento do Estado quanto às relações produtivas da economia. Este recuo foi acompanhado do início do processo de reprimarização de exportações, advindo do novo ambiente externo - explosão dos preços das commodities e do "Efeito China". 
As reformas liberalizantes no Uruguai visavam a diminuição do processo inflacionário e do déficit público, e para tanto foram implementadas políticas de restrição fiscal e o instrumento do câmbio, aliado a abertura comercial e financeira (que visava atrair capitais para sustentar a âncora cambial). Assim mesmo, esses fatores contribuíram para o processo de desindustrialização. Na década de 2000, quando superada a preocupação com a estabilização, que se tornou o principal objetivo da política econômica na década anterior, a política econômica do governo pôde manejar um conjunto mais amplo de instrumentos de política econômica e a introdução de reformas institucionais e sociais que deram possibilidade à indústria para aumentar sua participação, revertendo o processo de desindustrialização em um grau maior do que ocorreu na Argentina. A dinâmica da pauta de exportações foi a mesma que a da Argentina: início da reprimarização das exportações nos anos 2000.

No Paraguai, tanto na década de 1990 quanto na de 2000, a pesquisa não encontrou evidências consistentes para apontar a ocorrência do processo de desindustrialização, pois os indicadores são conflitantes ou insuficientes. Não foi diagnosticada uma reprimarização da pauta de exportações paraguaia. Isto pode ser explicado pela pauta de exportações já altamente concentrada e dependente de matérias-primas e bens intermediários.

\section{CONSIDERAÇÕES FINAIS}

O presente trabalho objetivou verificar a possível ocorrência de um processo de desindustrialização nos países que inicialmente compuseram o bloco econômico do MERCOSUL, bem como a possível relação entre o referido fenômeno e as políticas econômicas adotadas pelos governos dos países em questão, no período compreendido entre 1990 e 2012.

Diante de todas as informações obtidas e em razão da complexidade do tema, não foi possível fundamentar uma conclusão geral e unívoca da desindustrialização no MERCOSUL. Ou seja, há singularidades em cada país. O que pode ser constatado é que alguns países do bloco econômico apresentaram indícios de desindustrialização em certos períodos de tempo.

Não há evidências suficientes para afirmar que no período de análise o Brasil passou pelo processo de desindustrialização, com exceção ao período pós-crise. Mas como é um subperíodo restrito é insuficiente para configurar um processo de desindustrialização, podendo ser apenas um declínio conjuntural. Enquanto na década de 1990 pode-se dizer que não houve reprimarização da pauta de exportações, na década de 2000 há evidências que apontam para o processo.

Na década de 1990 há indícios da ocorrência do processo de desindustrialização na Argentina, sem reprimarização da pauta de exportações. Já os dados da economia argentina pós-2003 não permitiram inferir a continuação do processo de desindustrialização, havendo parcial reversão do processo iniciado na década anterior e o início da reprimarização.

Em relação ao Uruguai pode-se auferir que houve um processo de desindustrialização na década de 1990 sem reprimarização da pauta de exportações, porém a partir de 2005 os dados mostram que houve certa reversão. 
No tocante ao Paraguai, os dados revelam que a indústria paraguaia não é muito forte. Ademais a economia do país se mostrou frágil, sem grandes mudanças, não permitindo fundamentar uma consideração. A dificuldade de análise do Paraguai é decorrente do baixo nível de desenvolvimento industrial do país e a escassa literatura foi um entrave.

A relação entre desindustrialização e reprimarização de exportações apresentou resultados interessantes. São fenômenos que podem estar relacionados, mas não necessariamente. Os casos de Argentina e Uruguai na década de 1990 evidenciam que pode ocorrer desindustrialização sem reprimarização das exportações, e neste caso a hipótese da "nova doença holandesa" - que relaciona políticas econômicas e desindustrialização parece plausível. Também pode ocorrer reprimarização das exportações, sem desindustrialização, conforme os casos do Brasil pós-2000 e os casos de reversões de Argentina e Uruguai na mesma época.

Quanto ao tema da reprimarização de exportações, com exceção do Paraguai, percebeu-se a mesma dinâmica para todos os países: ocorrência a partir da década de 2000 . Isto sugere que seus condicionantes estão ligados em maior grau à dinâmica externa: boom dos preços das commodities e a maior demanda chinesa.

Diante disso, fica a sugestão para trabalhos posteriores de levantar informações em outros níveis de desagregação e classificações da indústria e das exportações no nível setorial que possibilitem entender mais a fundo as mudanças recentes da estrutura produtiva e industrial desses países e inferir novos diagnósticos. Não obstante, alargar o recorte temporal pode ser interessante para verificar o comportamento da indústria, por exemplo, antes da década de 1990 e observar de forma mais evidente comportamento da indústria quando das políticas econômicas e reformas durante a década de 1990. Outra perspectiva é analisar os dados para o período posterior a 2012.

A aquisição de informações sobre tal problemática é demasiada relevante, visto que a indústria é um dos setores mais competitivos e dinâmicos da economia de um país, ainda mais num contexto de integração regional.

\section{REFERÊNCIAS}

ALMEIDA, Paulo Roberto. O desenvolvimento do MERCOSUL: progressos e limitações. Brasília: Revista Espaço da Sophia, ano 5, nº 43, 2011, p.143-170.

ANTÍA, Fernando. La economía uruguaya en 1985-2000: políticas económicas, resultados y desafíos. Instituto de Economía. Montevideo, 2001. (Series documentos de trabajo, D.T. $4 / 01)$.

BATISTA, Paulo Nogueira. O Consenso de Washington: a visão neoliberal dos problemas latino-americanos. Caderno da dívida externa, PEDEX, São Paulo: Peres, n. 69, 1994. Disponível em: $<$ http:/www.usp.br/fau/cursos/graduacao/arq_urbanismo/ disciplinas/aup0270/4dossie/nogueira94/nog94-cons-washn.pdf > . Acesso em 05 maio 2016. 
BITTENCOURT, G.; RODRÍGUEZ A.; TORRES, S. Factores clave para el crecimiento económico sostenido en Uruguay”. Serie Estrategia Uruguay IIIS Doc.01/09. Área Estrategia de Desarrollo y Planificación Oficina de Planeamiento y Presupuesto - Presidencia de la República, 2009.

BONELLI, R.; PESSÔA, S.A. “Desindustrialização no Brasil: um resumo da evidência”. Texto para Discussão no 7 . FGV/IBRE, 2010.

BRASIL. Ministério do Desenvolvimento, Indústria e Comércio Exterior (MDIC). Secretaria de Comércio e Serviços. Oportunidades de Negócios com o Paraguai. 2008. Disponível em: <http://www.desenvolvimento.gov.br/arquivos/dwnl_1224528389.pdf >. Acesso em: maio de 2016.

Presidência da República. Decreto No 350, de 21 de novembro de 1991. Promulga o Tratado para a Constituição de um Mercado Comum entre a República Argentina, a República Federativa do Brasil, a República do Paraguai e a República Oriental do Uruguai e dá outras providências. Brasília, DF, 1991. Disponível em: <http://www.planalto.gov.br/ ccivil_03/decreto/1990-1994/d0350.htm>. Acesso em: 16 mar. 2018.

BRESSER-PEREIRA, L.C; THEUER, D. Um Estado novo-desenvolvimentista na América Latina?. Economia e Sociedade, v. 21, p. 811-829, dez. 2012.

BUSTOS, Pablo. Cono Sur: Auge, crises y recuperacíon. In: Consenso Progresista: política económica de los gobiernos del Cono Sur: elementos comunes, diferencias y aprendizajes. 1.ed. Buenos Aires, 2010.

CANO, Wilson. A desindustrialização no Brasil. Texto para Discussão. IE/UNICAMP n. 200, p.831-851, 2012.

CAVUSGIL, S.T; KNIGHT, G; RIESENBERGER, J.R. Negócios internacionais: estratégia, gestão e novas realidades. São Paulo: Pearson Prentice Hall, 2010.

COLOMBINI NETO, Iderley. A trajetória de desenvolvimento recente na Argentina. In: ANPEC, Encontro Nacional de Economia. Anais... 2012.

FONSECA, Pedro Cezar Dutra. O Processo de Substituição de Importações. In: REGO, José Márcio; MARQUES, Rosa Maria Marques (org.). Formação econômica do Brasil. São Paulo: Saraiva, 2003, p.1-53.

FUNDAÇÃO CENTRO DE ESTUDOS DE COMÉRCIO EXTERIOR - Funcex. Disponível em: < http://www.funcex.org.br/:>. Acesso em 23 maio 2016.

GANTMAN, Ernesto R. Un modelo fallido de desarrollo: la experiencia argentina (19892001). Cuadernos de Relaciones Laborales. v. 30, 2012.

GIL, Antônio Carlos. Como elaborar projetos de pesquisa. 4. ed. São Paulo: Atlas, 2002.

ILHA, A. da; Rubin, L. Estabilização com Base no Câmbio: uma Análise Comparativa das Experiências da Argentina e do Brasil. Economia e Desenvolvimento, n. 13, 2001. 
INSTITUTO DE PESQUISA ECONÔMICA APLICADA (Ipeadata). Dados macroeconômicos e regionais. Disponível em: $<\mathrm{http}: / / \mathrm{www}$.ipeadata.gov.br/>. Acesso em 23 maio 2016.

LORENZO, Fernando. La política económica del primer gobierno del Frente Amplio. In: BUSTOS, Pablo. Consenso progresista: política económica de los gobiernos del Cono Sur: elementos comunes, diferencias y aprendizajes. 1.ed. Buenos Aires, 2010.

MERCOSUR. Países del MERCOSUR: Estados Partes e Estados Asociados. Disponível em: $<$ http://www.mercosur.int/innovaportal/v/7823/11/innova.front/paises-del-mercosur $>$. Acesso em 17 mar.2018.

MORDECKI, Gabriela. Principales objetivos e instrumentos de la Política Económica aplicada en Uruguay 1990-2002. Instituto de Economía, Notas de classe 1/03. 2002

MORINI, C.; SIMÕES, R. C. F. A Ordem Econômica Mundial: considerações sobre a formação de blocos econômicos e o Mercosul. Impulso, Piracicaba, v. 13, n. 31, 2002, p. 139-154.

NASSIF, André. Há evidências de desindustrialização no Brasil?. Brazilian Journal of Political Economy, v. 28, n. 1 (109), p. 72-96, Jan./March 2008.

OREIRO, J.L; FEIJÓ, C.A. "Desindustrialização: conceituação, causas, efeitos e o caso brasileiro”. Revista de Economia Política, v.30, n. 2, p.219-232, 2010.

PAOLINI, C; BONELLI, M. "Especialización agrícola y agroindustrial en Uruguay: ¿maldición o bendición? Anuario OPYPA, 2012.

PARAGUAY. Ministerio de Industria y Comercio. Negocios en el Paraguay: Elementos Del Costo País. 2007. Unidade técnica de estudios para la indústria. Disponível em:

$<$ http://www.mic.gov.py/v1/sites/172.30.9.105/files/Negocios\%20en\%20el\%20Paraguay.pdf >. Acesso em: 20 maio 2016.

PINTO, E. C. "A dinâmica dos recursos naturais no Mercosul na década de 2000: "efeito China", estrutura produtiva, comércio e investimento estrangeiro". In: Texto para discussão 005, Instituto de Economia, Universidade Federal do Rio de Janeiro, 2013.

SCHWARTSMAN, A. Uma tese com substâncias. Folha de São Paulo, São Paulo, ago. 2009.

WASQUES, R. N.; TRINTIN, J. G. Uma Análise do Desempenho da Indústria de Transformação Brasileira na Década de 1990: Ocorreu um Processo de Desindustrialização? . XL Encontro Nacional de Economia, Anais... 2014.

WORLD BANK. World Development Indicators Database. Employment in industry (\% of total employment). World Bank, 2016. Disponível em: $<$ http://databank.worldbank.org/data/ reports.aspx?Code=NY.GNP.PCAP.PP.CD\&id=af3ce82b\&report_name=Popular_indicators \&populartype $=$ series\&ispopular $=\mathrm{y} \#>$.Acesso em: 19 maio 2016. 
. World Development Indicators Database. GDP at market prices (constant 2005

US\$); Industry, value added (constant 2005 US\$); Manufacturing, value added (constant 2005 US\$). World Bank, 2016. Disponível em: <http://databank.worldbank.org/data/ reports.aspx ?Code=NY.GNP.PCAP.PP.CD\&id $=$ af3ce82b\&report_name=Popular_indicators $\&$ populartype $=$ series $\&$ ispopular $=\mathrm{y}>$. Acesso em 18 maio 2016.

World Development Indicators Database. GDP annual. World Bank, 2018.

Disponível em: < http://databank.worldbank.org/data/reports.aspx?

Code=NY.GDP.MKTP.KD.ZG\&id=1ff4a498\&report_name=Popular-

Indicators\&populartype $=$ series\&ispopular $=\mathrm{y}>$.Acesso em 18. $\operatorname{mar} 2017$.

UN COMTRADE. WORLD INTEGRATED TRADE SOLUTION DATABASE. 2011.

Export Product Share (\%). Disponível em: < https://wits.worldbank.org/\#void $>$. Acesso em 24 maio 2016.

Artigo recebido em: 16/10/2017

Artigo aprovado em: 21/03/2018 